\title{
Politycy i eksperci - Polska i USA w obliczu pandemii COVID-19
}

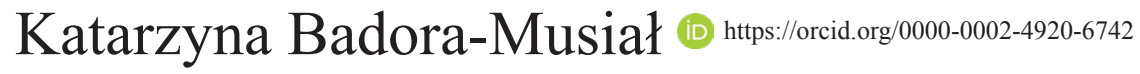 \\ Dominika Dusza 1 h htps://orid.orgy $0000-0002-3100-718 x$
}

Zakład Polityki Zdrowotnej i Zarządzania, Instytut Zdrowia Publicznego, Wydział Nauk o Zdrowiu, Uniwersytet Jagielloński Collegium Medicum

Adres do korespondencji: Katarzyna Badora-Musiał, Instytut Zdrowia Publicznego, ul. Skawińska 8, 31-066 Kraków, kasia.badora@uj.edu.pl

\section{Abstract}

\section{Politicians and Experts - Poland and USA during pandemic COVID-19}

During pandemic COVID-19, politicians responsible for developing strategies to combat the virus play a significant role and make key decisions in this regard. An important role is also played by national experts who advise and provide scientific knowledge to governments to ensure the highest possible level of security for the whole society. The analysis of Polish and American politicians and experts gives a comparison in terms of actions, opinions and positions taken. In both countries, important national expert institutions participated in the fight against the pandemic, and government advisory teams for the COVID-19 pandemic were established. There were numerous problems with both health systems and a lack of consistency between the recommendations of experts and politicians, which resulted in a loss of public confidence. This difficult situation in which all countries in the world find themselves may be a good lesson for future threats.

\section{Key words: COVID-19, Donald Trump, experts, politicians, Poland, USA, trust}

\section{Stowa Kuluczowe: COVID-19, Donald Trump, eksperci, politycy, Polska, USA, zauffanie}

\section{Wprowadzenie}

Teoretycy demokracji, badając napięcia między ekspertami a wybranymi politycznymi urzędami, zastanawiają się, kto powinien podejmować decyzje w zarządzaniu publicznym. Z jednej strony eksperci dysponują specjalistyczną, wysoce techniczną wiedzą niezbędną do rozwiązywania złożonych problemów; nie zostali jednak wybrani do podejmowania decyzji, co może być zarówno dobre, jak i złe, nie odpowiadają bowiem przed obywatelami i są odizolowani od presji publicznej. $Z$ drugiej strony wybierani liderzy mogą ulec pokusie, by rozpieszczać wyborców lub grupy interesu i mają mniej wiedzy technicznej, na której mogliby opierać swoje decyzje.

$\mathrm{W}$ teoretycznym schemacie podział zadań między ekspertami i politykami jest klarowny: eksperci dostarczają wiedzę w postaci czytelnej dla decydentów (uczestników procesu decyzyjnego), a politycy podejmują decyzję, przy założeniu, że czynią to w najlepszej wierze, traktując dobro wspólne jako cel dokonywanych wyborów. Kryterium, jakim mają się posługiwać badacze, jest normatywnie oczywiste - to kryterium prawdy, a metody służące jej dochodzeniu czy weryfikowaniu przedstawianych hipotez podlegają zasadom ustalonym $\mathrm{w}$ akceptowanym współcześnie paradygmacie metodologicznym. Natomiast kryteria, jakimi mają posługiwać się politycy, nie są tak jednoznaczne. Mimo że arystotelesowska zasada wspólnego dobra deklaratywnie jest jeszcze niekiedy powtarzana, zwłaszcza przez przeciwników politycznych, to praktyka ostatnich lat wyraźnie temu przeczy. Coraz częściej argumenty przedstawiane w języku politycznych wystąpień są celowo adresowane do wybranych segmentów społeczeństwa w sposób, który inne grupy społeczne wewnątrz kraju albo poza jego granicami - identyfikowane w dowolny sposób - wyraźnie wskazują jako zły. Negatywna kwalifikacja takich działań może wiązać się z nagannym zachowaniem członków tych grup w przeszłości. Mogli oni bowiem doprowadzić do krzywdy tych, w imieniu których polityk występuje, albo - ze względu na swoje cechy - mogą stać się zagrożeniem na przyszłość. Charakterystyki grup przedstawianych jako wrogie mogą tak naprawdę nie mieć większego wpływu na kształtowanie rzeczywistości. Dla autora przekazu kryterium prawdy nie ma jednak żadnego znaczenia, liczy się 
jedynie skuteczność oddziaływania na odbiorcę i wywołania w nim pożądanych emocji. Ponieważ we współczesnych społeczeństwach zwykle łatwiej jest wzbudzać emocje negatywne, związane z zawiścią, lękiem i gniewem, politycy dążący do skuteczności najczęściej odwołują się właśnie do nich. Gniew można wykorzystywać do wspierania radykalnych postulatów przywracania sprawiedliwości, a poczucie lęku pozwala na kreowanie heroicznej postaci zdolnej obronić zagrożonych ludzi przed nadchodzącym wrogiem. Doświadczenia ostatnich lat wskazują, że bezpośrednim celem jest zdobywanie władzy poprzez zwycięstwo wyborcze - więc zwolennicy tego rodzaju retoryki akcentują zgodność stosowanych metod z wymogami demokracji - ale historyczne wspomnienia $\mathrm{z}$ lat 30. ubiegłego wieku przypominają, że nie ma żadnych gwarancji, że wybory pozostaną jedynym mechanizmem wykorzystywanym do zdobywania, a zwłaszcza utrzymywania władzy.

Dla zwolenników posługiwania się lękiem jako narzędziem politycznego działania pojawienie się pandemii tworzy warunki bardzo korzystne. Epidemia już od czasów starożytnych w naturalny sposób tworzy atmosferę zagrożenia. Tak się złożyło, że epidemie przychodziły do Europy „od obcych”, historycznie na ogół ze Wschodu, i wymyślony kordon sanitarny naprawdę miał chronić przed zarazą [1]. COVID-19 także przywędrował ze Wschodu, powszechnie znana stała się nazwa odległej prowincji Wuhan, a tajemnicze mutacje wirusa z udziałem nietoperzy [2] wzmacniały poczucie tajemniczej grozy. Wirus był nowy, więc eksperci nie znali jego charakterystyk, a zwłaszcza wielkości stwarzanego przezeń zagrożenia dla ludzi [3]. Warto przypomnieć, że początkowo nie potwierdzano możliwości wzajemnego zakażania się ludzi $[4,5]$. Jedyną pewną informacją było to, że ludziom grozi zainfekowanie o nieznanych konsekwencjach, ale z możliwością śmierci. Jednocześnie nie istniało żadne skuteczne antidotum, więc systemy zdrowotne były w znacznej mierze bezsilne, a jedynym dostępnym środkiem reagowania była izolacja, czyli wymyślona przed wiekami kwarantanna, utrudniająca krążenie wirusa i rozprzestrzenianie się epidemii. Izolacja, a więc eliminacja albo przynajmniej radykalne ograniczenie kontaktów między ludźmi, była jednoznaczna $\mathrm{z}$ drastycznym ograniczeniem wolnościowych praw obywatelskich. W ich wyniku zamrażano wiele społecznych procesów, takich jak działanie instytucji edukacyjnych, usługowych, wytwórczych, kulturalnych i religijnych, wszystkich, w których dochodzi do kontaktu między ludźmi. Restrykcje niemożliwe do zastosowania w innych warunkach, po nadejściu epidemii i ogłoszeniu stanu zagrożenia, były akceptowane bez sprzeciwu. Należy dostrzec, że ludzie sprawujący władzę zaczęli korzystać nie tylko z możliwości wprowadzania obostrzeń, ale także z możliwości ich znoszenia. Stan epidemii umożliwił więc skomplikowaną grę siłą i zakresem obowiązujących restrykcji, a różne siły polityczne i grupy interesów zaczęły zajmować stanowiska, postulując mniej lub bardziej rygorystyczną ich postać. W bardzo dużym uproszczeniu wskazać można kilka charakterystyk tych różnic. Po pierwsze, można powiedzieć, że eksperci, zwłaszcza zajmujący się zdrowiem publicznym, byli zwolennikami większych ograniczeń i wolniejszego tempa ich liberalizacji (choć nie zawsze byli jednomyślni w tej sprawie), natomiast przedstawiciele kół biznesowych chcieli możliwie szybkiego odmrażania gospodarki. Po drugie, wśród polityków zwolennicy liberalnej demokracji byli skłonni przestrzegać restrykcji i z dużą ostrożnością wycofywać się z wprowadzonych wcześniej ograniczeń, natomiast przedstawiciele orientacji populistycznej z pewnym lekceważeniem traktowali ograniczenia, przyznając pierwszeństwo wolności gospodarczej i swobodnym decyzjom uczestników życia gospodarczego. Orientacja polityczna wpływała także na sposób traktowania indywidualnych zachowań, takich jak noszenie maseczek czy zachowanie dystansu społecznego. Po trzecie, politycy, przynajmniej niektórzy, wykazali skłonność do wysoce instrumentalnego traktowania opinii ekspertów na temat sytuacji epidemicznej, a zwłaszcza ustalenia etapu jej zaawansowania. O ile w fazie narastania epidemii ograniczenia są w pełni usprawiedliwione, o tyle liberalizacja powinna następować dopiero w fazie, kiedy epidemia ustępuje. Podejmowana przez polityków manipulacja polegała zatem na przyznaniu sobie kompetencji określenia etapu epidemii, bez oglądania się na opinie ekspertów.

\section{Metody analizy}

Zakres analizy został celowo ograniczony do dwóch grup decydentów - polityków i ekspertów - z powodu przyjęcia założenia, że w wyjątkowej sytuacji pandemii społeczeństwo - oczywisty suweren demokratycznych krajów - zostało sprowadzone do roli podmiotu całkowicie biernego. Nie nastąpiło to $\mathrm{w}$ żadnej mierze jako rezultat opisywanego od pewnego czasu kryzysu demokracji, ale z powodu lub pod pretekstem, zagrożenia masowymi zachorowaniami i masowymi zgonami. W zbiorowej pamięci ludzkości są wspomnienia dramatycznych doświadczeń z przeszłości - między innymi pandemia grypy hiszpanki z początku XX wieku, która przyniosła miliony ofiar - nic zatem dziwnego, że lęk stał się podstawowym wyznacznikiem społecznych i politycznych zachowań. W związku z tym, że wiedza na temat nowego wirusa nie istniała, nie mówiąc o możliwości skorzystania ze skutecznych terapii, nadzieje wielu były kierowane pod adresem ekspertów. Mogła to być dla nich jakaś satysfakcja po okresie okazywanego przez populistów braku zaufania do wiedzy pochodzącej z wykształcenia.

Za eksperta można uznać kogoś, kto charakteryzuje się następującymi cechami: (a) motywacją i skupieniem; (b) dobrym wykształceniem; (c) solidnym doświadczeniem w jakiejś dziedzinie; (d) znaczącymi osiągnięciami; (e) doskonałą reputacją; (f) prestiżową pozycją; oraz (g) brakiem osobistego interesu w przedmiotowej sprawie. Ekspertem jest więc osoba, która zazwyczaj posiada wysoki stopień naukowy z renomowanej instytucji i ma duże doświadczenie w swojej dziedzinie. Jest to jednak także osoba, która osiągnęła znaczące wyniki w swojej dziedzinie, ciesząca się dużym uznaniem wśród współpracowników oraz zajmująca prestiżowe stanowiska (np. w ważnych instytucjach). Aby ekspertowi można było zaufać, powinien być on także stroną 
bezinteresowną, nie może mieć więc żadnego udziału w jakimś konkretnym przekonaniu. Dodatkowo musi być zmotywowany i skupiony na swoich badaniach; nie może chcieć iść na kompromis w celu uzyskania natychmiastowej nagrody. Są to cechy, które razem wzięte mogą uczynić z kogoś eksperta i zapewnić mu większy epistemiczny autorytet (a tym samym wiarygodność) W stosunku do osób niebędących ekspertami [6].

Wybór USA i Polski jako obiektów porównywanych z punktu widzenia formy reakcji politycznych i zarządczych wynika $\mathrm{z}$ dostępności do informacji o sytuacji w obydwu krajach, ale także $\mathrm{z}$ powodu podobieństw i różnic występujących między nimi. Wśród cech wspólnych wskazać należy zbliżony klimat polityczny polegający na populistycznym zapleczu, które doprowadziło do powierzenia władzy rządzącym ekipom; zarówno w kampanii wyborczej Donalda Trumpa w 2016 roku, jak i w kolejnych kampaniach partii Prawo i Sprawiedliwość istotną rolę odgrywało dążenie do polaryzacji społeczeństw i wyborców przez deklarowane wsparcie tych grup społecznych, które mogły poczuć się poszkodowane w wyniku zachodzących w ostatnich latach procesów gospodarczych i społecznych. Rok wybuchu pandemii był dla obu krajów także rokiem wyborów prezydenckich. Bardzo podobne okazało się chętne wykorzystywanie zagrożenia i poczucia autentycznych obaw żywionych przez społeczeństwo do forsowania własnych pomysłów politycznych władzy, także tych, które z COVID-19 nie miały nic wspólnego. Politycy w obydwu krajach mieli prawo nie mieć przygotowanych scenariuszy na sytuację nadchodzącego zagrożenia, wydaje się bowiem, że swoiste zadufanie polityków przekonanych, że dostępne im środki są wystarczające do oddalenia każdego ryzyka, niezależnie od jego natury, skutecznie uśpiło czujność zarówno rządzących, jak i opinii publicznej. W tej sytuacji wszyscy politycy, we wszystkich krajach, musieli zadeklarować konieczność polegania na wiedzy i doradztwie ekspertów, chociaż już miejsce ekspertów i sposób kontaktowania się władzy z nimi były różne. W jednej sprawie różnica między USA i Polską była uderzająca: efekty zdrowotne pierwszych etapów epidemii okazały się tragiczne w Stanach Zjednoczonych i bardzo łagodne (nieoczekiwanie łagodne) w Polsce. Chociaż na razie trudno jednoznacznie wskazać, co mogło być tego przyczyną, warto zauważyć, że pandemia ujawniła fundamentalne wady systemu opieki zdrowotnej w Stanach Zjednoczonych - brak dostępu i dysproporcje zdrowotne. Wysiłki republikanów doprowadziły do tego, że od federalnego roku budżetowego 2019 podatkowa „kara” za brak ubezpieczenia przestała obowiązywać, a wiele stanów odmówiło rozszerzenia Medicaid. Prawie 10\% Amerykanów nie ma ubezpieczenia, a $29 \%$ jest niedoubezpieczonych [7], co z pewnością jest kluczową barierą dla grup o niskich dochodach, jeśli chodzi o testowanie i leczenie COVID-19. Stany Zjednoczone - w odróżnieniu od Polski - są społeczeństwem wielokulturowym, wielorasowym i wielonarodowościowym. Z raportu Centers for Disease Control and Prevention (CDC), pokazującego dane na temat rasy/ pochodzenia etnicznego 580 hospitalizowanych pacjentów, wynika, że około 33\% pacjentów to Afroamerykanie, chociaż stanowią oni tylko $13 \%$ populacji USA, w porównaniu z $45 \%$ białymi pacjentami (76\% populacji) [8]. Wiele różnic dotyczy jednak podstawowych czynników, takich jak zły stan zdrowia, niski status społeczno-ekonomiczny, bariery w dostępie do opieki zdrowotnej wynikające z braku ubezpieczenia zdrowotnego, środowisko pracy i warunki życia. Polska pierwszy potwierdzony przypadek koronawirusa odnotowała później niż wiele krajów Unii Europejskiej czy USA (w tym przypadku 44 dni później). Dało to niewątpliwą przewagę w przygotowaniach do nowej sytuacji. Z analizy mobilności społeczeństwa wynika, że Polacy w pierwszych tygodniach pandemii ograniczyli przemieszczanie się blisko o połowę, co oznacza, że sumiennie i solidarnie podeszli do apelów władz i pozostali w domach [9].

Przy identyfikacji osób zaliczonych do grupy ekspertów zastosowano trzy kryteria. Po pierwsze, w obydwu krajach funkcjonowały instytucje, którym tradycyjnie, a także z racji merytorycznych kompetencji, przyznawano szczególne miejsce $\mathrm{w}$ ramach systemu zdrowia publicznego. W naturalny sposób osobom związanym z tymi instytucjami można było przypisywać rolę ekspertów. Po drugie, w obydwu krajach istniały formalnie definiowane stanowiska ekspertów czy doradców i wystarczało wskazać odpowiednie stanowisko, by wiedzieć, z czyją opinią ma się do czynienia. Podejmowane doraźnie formalne rozstrzygnięcia mogły polegać - i rzeczywiście polegały - na tworzeniu zespołów czy nawet sztabów doradczych, ukierunkowanych specyficznie na eksperckie wspieranie decydentów w podejmowaniu możliwie porządnie przygotowanych decyzji. Po trzecie, w czasie poprzedzającym pojawienie się pierwszych zachorowań, a potem w trakcie rozwoju epidemii pojawiały się osoby, które $\mathrm{z}$ racji merytorycznego przygotowania zabierały publicznie głos w sprawach dotyczących pojawienia się nowego wirusa, zagrożeń wywoływanych tym faktem oraz działań wskazywanych przez nich jako konieczne lub też zalecane, w celu minimalizowania niebezpieczeństwa. Opinie takie mogły być przekazywane bezpośrednio opinii publicznej, np. w telewizyjnych wystąpieniach, w wysłuchaniach organizowanych przez parlamentarne komisje i inne polityczne ciała, a także w innych formach publicznego komunikowania się.

\section{(Nie)jasne relacje między polityką a nauka}

Nauka i polityka są ze sobą zazwyczaj ściśle powiązane. Od polityków często oczekuje się, aby ich decyzje były podejmowane na podstawie badań naukowych czy analiz eksperckich. Politycy nie zawsze jednak są ekspertami w dziedzinie, w której podejmują decyzje ważne dla społeczeństwa. Od ekspertów natomiast wymaga się raczej, aby byli niezależni politycznie i aby ich przekonania oraz stanowiska zawsze były zgodne $\mathrm{z}$ dziedziną nauki, w której się specjalizują. To właśnie eksperci powinni wywierać większy wpływ na polityków poprzez swoje doradztwo, zwłaszcza w sytuacjach zagrożenia, jakim jest pandemia. W literaturze przedmiotu wskazuje się cztery różne teorie relacji między nauką a polityką, co graficznie przedstawia rysunek 1 . 


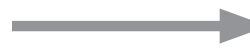

Polityka

2. Nauka

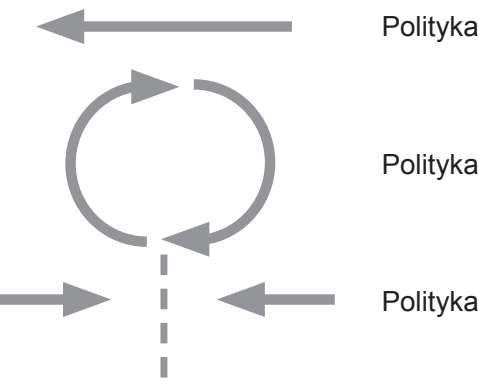

Rysunek 1. Relacje między polityką a nauką

Źródło: opracowanie własne na podstawie: C. Boswell, K. Smith, Rethinking Policy 'impact': Four Models of Research-Policy Relations, ,Palgrave Communications” 2017, vol. 3, https://doi.org/10.1057/s41599-017-0042-z, https://www. nature.com/articles/s41599-017-0042-z (dostep: 7.05.2021).

Według powyższego schematu należy wyróżnić cztery różne relacje/oddziaływania między nauką a polityką:

1. Nauka kształtuje politykę i wywiera na nią wpływ.

2. Polityka kształtuje naukę i wywiera na nią wpływ.

3. Nauka i polityka współpracują ze sobą, tworząc pewnego rodzaju kooperację.

4. Nie ma bezpośredniego związku przyczynowego między nauką a polityką.

Pierwsze podejście zakłada, że nauka jest bardzo istotna dla polityki, jednak jej wpływ jest często ograniczany przez problemy z komunikacją między przedstawicielami tych dwóch środowisk. Wiedza ekspercka często nie jest rozpowszechniana i przekazywana w formie przystępnej dla decydentów-polityków. Wiąże się to $\mathrm{z}$ utrudnionym procesem wykorzystania i stosowania tej wiedzy przez polityków w praktyce. Wskazuje się jednak na fakt, że wspólne zrozumienie między badaczami (ekspertami) i decydentami (politykami) poprawia wykorzystanie nauki w polityce. W związku z tym nacisk należy kłaść na poprawę mechanizmów komunikacji i poziomu zaufania między ekspertami a politykami.

Druga koncepcja w swojej mocniejszej interpretacji zakłada, że sam proces badawczy jest kształtowany przez „potężne interesy” kierujące programami politycznymi. Według tego ujęcia badania naukowe są przeprowadzane $\mathrm{w}$ celu wspierania wcześniej określonych preferencji politycznych, a niekiedy wykorzystywane jako metoda opóźniania procesu decyzyjnego. W pierwszym przypadku sam proces badawczy niekoniecznie zależy od polityki, ale decyzja o zastosowaniu danego badania (lub niezastosowaniu) jest całkowicie upolityczniona. Innymi słowy to, w jaki sposób politycy wykorzystują wiedzę ekspercką, można uznać za element gry politycznej. Ponadto samo zlecenie wykonania badań naukowych może być samo w sobie rozumiane jako akt polityczny (lub przynajmniej tworzyć polityczne korzyści). Stopień, w jakim polityka może kształtować naukę, jest prawdopodobnie najbardziej widoczny w przypadku badan, które są bezpośrednio zlecane przez grupy o określonych interesach politycznych. Przeglądy literatury wielokrotnie wykazywały, że badania finansowane ze źródeł komercyjnych (np. przemysł farmaceutyczny i tytoniowy) $\mathrm{z}$ większym prawdopodobieństwem przedstawiają wyniki korzystne dla tych grup interesów. Podobnie w sytuacji, gdy badania są zlecane bezpośrednio lub pośrednio przez instytucje na szczeblu rządowym - badacze mogą mieć trudności z utrzymaniem niezależności wyników badań.

Trzeci sposób postrzegania relacji między nauką a polityką zakłada o wiele bardziej złożone współzależności między nimi oraz to, że są wzajemnie konstytutywne. Wiedza naukowa i ekspercka w tej koncepcji przyczynia się do konstruowania rzeczywistości politycznej. Nauka dostarcza pojęć, danych i narzędzi, które stanowią podstawę wiedzy na temat problemów społecznych i politycznych oraz sposobów wykorzystania tej wiedzy. Teoria ta pokazuje również, w jaki sposób nauka może powodować problemy społeczne. Nie zawsze postęp naukowy przyczynia się do rozwiązywania problemów politycznych (problemów rządzenia), ale niekiedy tworzy nowe. Szybkie tempo rozwoju i postępu w nauce i technologii powoduje ciągły strumień nowych problemów i rozwiązań, z którymi rządy często walczą. Tak więc nowe badania mogą również zdestabilizować istniejące struktury i sposoby rządzenia. W obszarach polityki, które są w dużym stopniu zależne od technologii i nauki (takich jak energia, zdrowie, rolnictwo lub obrona), polityka próbuje „nadążać” za nauką - stara się wykorzystać i regulować nowe technologie i praktyki, które zostały dostarczone dzięki postępowi naukowemu. W ten sposób nauka stwarza nowe problemy, które wymagają interwencji politycznej. Zapotrzebowanie na coraz nowszą wiedzę ekspercką umożliwiającą rozwiązywanie tych problemów jest zatem wbudowane w relację między polityką a nauką.

Ostatnie podejście do tego zagadnienia traktuje naukę i politykę jako odrębne sfery, z których każda funkcjonuje według osobnej logiki i systemu. W relacji między nauką a polityką nie ma związku przyczynowego, brak też bezpośredniego wpływu między tymi dwoma systemami. Dlatego w koncepcji tej nie warto doszukiwać się przepływów, dyfuzji lub przyczynowości między nauką a polityką. Można zatem uznać, że w podejściu tym nauka działa zgodnie $\mathrm{z}$ binarnym kodem prawda-fałsz. Innymi słowy definiuje ona, co jest zgodne z prawdą, a co nie. Natomiast system polityczny posługuje się innym kodem: rząd-opozycja. Pomimo kierowania się odrębnymi kodami komunikacyjnymi systemy te mogą jednak selektywnie odbierać wzajemne sygnały.

Podsumowując, to, co składa się na wiedzę użyteczną politycznie, różni się zasadniczo od tego, co nazywamy wiedzą ekspercką. Może się zdarzyć, że polityka musi „kontrolować jakość” nauki, do której się odwołuje, aby zabezpieczyć się przed jej unieważnieniem przez krytyków. Niekiedy nauka stanowi także swoiste zabezpieczenie przed popełnieniem błędów, które mogłyby skutkować utratą poparcia politycznego. Polityka zatem nie jest zasadniczo zajęta tym, co jest prawdą, ale tym, co jest istotne dla zapewnienia władzy i wydawania zbiorowo wiążących decyzji. 


\section{Rola ekspertów i polityków}

W przypadku bezprecedensowej pandemii należy zadać sobie pytanie, skąd pochodzą rozsądne dowody potrzebne decydentom. Bogenschneider i Corbett [10] zidentyfikowali trzy kryteria dla dowodów spełniających standardy użyteczności dla decydentów: (a) wiarygodność - wysoka jakość naukowa i bezstronność, (b) dostępność - łatwo zrozumiałe oraz (c) aktualność dostępne w momencie podejmowania decyzji. W przypadku nagłej pandemii, takiej jak COVID-19, zwłaszcza na jej etapach powstawania i rozprzestrzeniania się, wiarygodne, dostępne i aktualne dowody mogą po prostu nie istnieć w wielu obszarach, takich jak pochodzenie wirusa, mechanizmy przenoszenia, współczynnik śmiertelności i wzór mutacji.

Po wybuchu pandemii koronawirusa większość światowych przywódców zaczęła apelować do ekspertów medycznych i ich epistemicznego autorytetu o uzasadnienie wprowadzenia niepopularnych środków bezpieczeństwa (jak np. wymuszona kwarantanna), uznanych za najbardziej odpowiednie dla spowolnienia rozprzestrzeniania się COVID-19. Motywacją do tego kroku były co najmniej dwa elementy. Z jednej strony władze polityczne dostrzegały, że ich zwykłe działania są nieskuteczne i musiały w pełni wykorzystywać wiedzę medyczną, często w zasadzie delegując strategie i decyzje ekspertom (np. wdrażając je i rozwiązując wszelkie konflikty między różnymi podmiotami społecznymi, jak np. między związkami zawodowymi a pracodawcami pierwsi byli bardziej skłonni do zamykania fabryk dla bezpieczeństwa pracowników, drudzy do utrzymywania ich otwartych ze względów ekonomicznych). Z drugiej strony, odwołując się do epistemicznego autorytetu ekspertów, politycy tak naprawdę zwalniają się z odpowiedzialności za dokonane wybory, zwłaszcza jeśli nie są mile widziane przez opinię publiczną, są nieskuteczne lub mają nieprzewidziane negatywne skutki uboczne. W rzeczywistości dynamika, która sprawia, że eksperci odgrywają centralną rolę w polityce, może powodować problemy same w sobie, ponieważ strategie proponowane przez ekspertów są często dalekie od neutralności w odniesieniu do wartości, które pluralistyczne społeczeństwo uważa za istotne [6].

\section{Instytucje eksperckie w USA}

Do eksperckich instytucji amerykańskich należy zaliczyć przede wszystkim Centrum Zapobiegania Chorobom (Centers for Disease Control and Prevention - CDC). Instytucja ta powstała w końcówce lat 40. XX wieku; zajmowała się wówczas chorobami zakaźnymi, głównie malarią, z czasem stała się jednym z wiodących ośrodków kształtowania koncepcji zdrowia publicznego, nie tylko w USA, ale i w skali międzynarodowej [11]. Jak napisano w misji instytucji: „CDC jest wyjątkową agencją z wyjątkową misją: pracujemy 24 godziny na dobę, przez siedem dni w tygodniu, aby chronić bezpieczeństwo, zdrowie i zabezpieczenie Ameryki przed zagrożeniami występującymi na miejscu i na całym świecie" [12].
Jednak CDC, które dotychczas udostępniało do wiadomości publicznej liczne doniesienia o sytuacjach kryzysowych $\mathrm{w}$ zdrowiu publicznym, podczas pandemii COVID-19 zrezygnowało z organizacji konferencji prasowych [13]. Osłabione cięciami budżetowymi i osobowymi nie było w stanie w odpowiednim czasie i dokładnie zebrać i przeanalizować niektórych statystyk, które są kluczowe dla zarządzania kryzysami zdrowia publicznego. Podczas pandemii COVID-19 to organizacje pozarządowe, takie jak Centrum zasobów dotyczące koronawirusa Uniwersytetu Johnsa Hopkinsa (Community Resource Center - CRC) [14], Kaiser Family Foundation [15] i 1Point3Acres [16], zapewniały społeczeństwu aktualne i wyczerpujące statystyki. Warto zauważyć, że CRC pozostaje jednym z najbardziej wiarygodnych źródeł informacji na temat zakresu i rozwoju pandemii [17]. Rzetelność informacji, gwarantowana niezależnością samodzielnej uczelni, wpłynęła prawdopodobnie na decyzję rządu nakazującą szpitalom przekazywanie informacji bezpośrednio do Departamentu Zdrowia i Opieki Społecznej (Department of Health and Human Services DHHS), co zdecydowanie spowolniło proces udostępniania nowych danych [18].

Kolejną instytucją jest Narodowy Instytut Alergologii i Chorób Zakaźnych (The National Institute of Allergy and Infectious Diseases - NIAID), który szczyci się historią sięgającą szpitala marynarki wojennej z końca XIX wieku [19]. NIAID jest jedną z 27 placówek wchodzących w skład konglomeratu narodowych instytutów zdrowia, skupiającego najważniejsze instytucje badawcze i koncentruje się głównie na programach badawczych [20]. Od 1984 roku dyrektorem tej instytucji jest Anthony Fauci, który doradzał sześciu prezydentom w wielu kwestiach zdrowotnych w kraju i na świecie.

\section{Amerykański zespót doradczy ds. pandemii COVID-19}

Grupa Zadaniowa Białego Domu ds. Koronawirusa (tzw. Prezydencka Grupa Robocza), mająca koordynować działania administracji i sektora zdrowotnego w podejmowaniu wysiłków chroniących populację przed rozprzestrzenianiem się wirusa i jego skutkami, formalnie została utworzona 29 stycznia 2020 roku [21], ale już trzy dni wcześniej prezydent Trump poinformował, że przewodniczącym zespołu będzie wiceprezydent Mike Pence, a koordynatorem jego prac dr Deborah Brix [22] $]^{1}$. Początkowo zespół liczył 11 członków, w tym dyrektorów wskazanych wcześniej profesjonalnych instytucji, także dyrektora Narodowego Instytutu Zdrowia (National Institutes of Health - NIH), ale bez udziału przedstawicieli Uniwersytetu Johnsa Hopkinsa, szefów lub przedstawicieli najważniejszych resortów; jego skład był z czasem uzupełniany [23]. Zastrzec jednak należy, że nie wszyscy członkowie zespołu mogą być traktowani jako eksperci. Zgodnie ze znaczeniem słów przyjętym w tym tekście, pojęcie to jest ograniczone do profesjonalistów medycznych i tylko takie przygotowanie tworzyło podstawy uznania członka zespołu za eksperta. Inne niż medyczne przygotowanie zawodowe - specjaliści w innych dziedzinach - eliminowało z grona ekspertów. Jeśli 
zatem autorem jakiejś wypowiedzi był na przykład ekonomista Larry Kudlow, to nie była ona traktowana jako wypowiedź ekspercka [24]2.

Przez pewien czas członkowie zespołu występowali w różnych konfiguracjach, wspólnie z prezydentem i wiceprezydentem na briefingach poświęconych COVID-19, ale zabierali także głos w politycznych wysłuchaniach. Stanowisko ekspertów było w zasadzie jednolite i ograniczało się wyraźnie do spraw związanych bezpośrednio z epidemią, choć mogło odnosić się także do ocen dotyczących różnych przedsięwzięć zapobiegawczych, zwłaszcza jeśli eksperci byli o to pytani w czasie parlamentarnych wysłuchań. Publicznie najbardziej aktywną i zabierającą głos osobą w tej grupie był Anthony Fauci3. Wspomniane wcześniej opracowania przygotowywane przez instytucje profesjonalne są naturalnie traktowane jako wypowiedzi eksperckie, podobnie jak pojedyncze głosy badaczy przedstawiane opinii publicznej.

\section{Amerykaíscy politycy}

W amerykańskich realiach nie było trudności w identyfikowaniu wypowiedzi jako eksperckich lub politycznych. W najmniejszym stopniu nie dotyczyło to treści, ale było efektem jednoznacznego definiowania ról podejmowanych przez poszczególne podmioty. Politykiem, który przez długi czas zabierał głos w czasie regularnych briefingów, był prezydent Donald Trump, znacznie rzadziej wiceprezydent Mike Pence. Prezydent informował nie tylko o decyzjach podejmowanych przez rząd federalny, o możliwych do wprowadzenia przez gubernatorów poszczególnych stanów rozwiązaniach ${ }^{4}$, zwłaszcza tych odnoszących się do zaostrzania lub liberalizowania lockdownu, ale także o swoich poglądach dotyczących różnych aspektów epidemii.

Przed pandemią prezydent Trump nie omawiał szczegółowo kwestii zdrowia publicznego, a kiedy to robił, często wprowadzał opinię publiczną w błąd. Podczas kampanii prezydenckiej w 2016 roku poświęcił tylko niewielką część przemówień wyborczych, reklam, kampanii i wywiadów zagadnieniom zdrowia publicznego [25]. Jako prezydent nadal nie poświęcał zbyt dużej uwagi kwestiom zdrowia publicznego, koncentrując się głównie na dyskusjach wokół wysiłków Partii Republikańskiej w celu uchylenia tzw. Obamacare [26].

Wrogość Trumpa wobec biurokratycznych doświadczeń w walce z pandemią COVID-19 zaczęła się na długo przed rozpoczęciem samej pandemii. Prezydent Barack Obama w 2016 roku utworzył biuro reagowania na pandemię w ramach Rady Bezpieczeństwa Narodowego (National Security Council - NSC), traktując grypę jako największe zagrożenie dla bezpieczeństwa zdrowotnego narodu. Na jego czele stał R. Timothy Ziemer, który był szanowanym specjalistą $\mathrm{w}$ dziedzinie zdrowia publicznego, kierującym Inicjatywą Prezydencką w sprawie Malarii (U.S. President's Malaria Initiative) pod rządami George'a W. Busha i Baracka Obamy [27]. Jednak w czasie prezydentury Trumpa w kwietniu 2018 roku, za pośrednictwem doradcy ds. bezpieczeństwa narodowego Johna Boltona, zamknięto biuro w ramach usprawnienia działań NSC. Trump pytany o konsekwencje ogromnych cięć w CDC, NIH i Światowej Organizacji Zdrowia (World Health Organization - WHO), odpowiadał: „Nie lubię mieć wokół siebie tysięcy ludzi, których nie potrzebuję. Kiedy będziemy ich potrzebować, możemy ich bardzo szybko odzyskać" [28]. Pokazuje to jego podejście do ekspertów. Rozwiązanie zespołu reagowania na pandemię sprawiło, że administracja Trumpa była znacznie gorzej przygotowana do zajęcia się pandemią COVID-19 niż mogłaby być, gdyby do niego nie doszło.

Pierwszy przypadek COVID-19 w Stanach Zjednoczonych potwierdzono 20 stycznia 2020 roku, kilka dni później (29 stycznia) prezydent Donald Trump powołał Grupę Zadaniową Białego Domu ds. Koronawirusa (White House Coronavirus Task Force), której celem było „monitorowanie, powstrzymywanie i łagodzenie rozprzestrzeniania się wirusa". Jednak prezydent od początku bagatelizował zagrożenie, twierdząc, że ma wszystko pod kontrolą [29], kilkakrotnie odrzucał porady ekspertów własnej grupy zadaniowej [30]. Pomimo upoważnienia Federalnej Agencji Zarządzania Kryzysowego (Federal Emergency Management Agency - FEMA) do czasu ogłoszenia 13 marca 2020 roku deklaracji nadzwyczajnej COVID-19 prezydent nie poparł poważnych zmian w polityce, a agencje federalne nie zastosowały nadzwyczajnych uprawnień do ograniczenia zachowań obywateli (z wyjątkiem międzynarodowych zakazów podróżowania). W konsekwencji większe ograniczenia zostały wprowadzone dopiero na poziomie stanowym. Trump wysuwał różne twierdzenia, które nie miały naukowego podłoża. Najważniejszym z nich było to o rzekomych metodach leczenia COVID-19 lekami przeciwmalarycznymi - chlorochiną i hydroksychlorochiną - czy antybiotykiem azytromycyną, a pod koniec kwietnia „zastrzykami dezynfekującymi” i ,światłem UV" [31]. Wspierając tych, którzy postrzegają maski jako naruszenie osobistego wyboru i wolności osobistej, przy wielu okazjach odmawiał noszenia maski, wbrew zaleceniom zdrowia publicznego, w tym poradom jego własnych urzędników służby zdrowia, z których część publicznie zdyskredytował [32].

\section{Polskie instytucie etsperchie}

W Polsce wiodącą instytucją w zakresie zdrowia publicznego jest Narodowy Instytut Zdrowia Publicznego, przekształcony $\mathrm{z}$ zasłużonego Państwowego Zakładu Higieny, którego aktywność sięga okresu przedwojennego. W ostatnim okresie instytucja została organizacyjnie wzmocniona przez inkorporację funkcjonującego oddzielnie Instytutu Żywności i Żywienia. W lipcu 2021 roku po zmianie statusu została przemianowana na Narodowy Instytut Zdrowia Publicznego PZH - Państwowy Instytut Badawczy (NIZP PZH - PIB), zyskując nowe zadania i finansowanie. W jej dumnie brzmiącej misji napisano: „Znajdujemy rozwiązania, dzięki którym ludzie mogą żyć zdrowo, długo i aktywnie. Zapewniamy badaniom i rozwiązaniom wiarygodność naukową i umożliwiamy korzystanie z nich wszystkim, którzy troszczą się o zdrowie swoje i całego społeczeństwa" [33]. Obecnie w zakresie 
zainteresowań naukowych Instytutu znajdują się: problematyka zapobiegania chorobom zakaźnym i ważnym społecznie chorobom niezakaźnym, monitoring sytuacji zdrowotnej, poprawa warunków sanitarnych i higienicznych, bezpieczeństwo środowiska naturalnego [34]. Wydawać się mogło, że NIZP PZH - PIB jest naturalnym zapleczem eksperckim na wypadek epidemii, biorąc pod uwagę, że ośrodki akademickie, w których prowadzone są studia ze zdrowia publicznego, nie mają stałej współpracy z ośrodkami władzy.

Inną instytucją mogła być także - działająca przy Głównym Inspektorze Sanitarnym - Rada Sanitarno-Epidemiologiczna, mająca w swojej strukturze Komisję Epidemiologii Chorób Zakaźnych i Szczepień Ochronnych. Jednak ten organ doradczy praktycznie nie został wykorzystany.

W Polsce specyficznym gronem osób kompetentnych w problemach medycznych są specjaliści krajowi i wojewódzcy zajmujący się poszczególnymi dziedzinami medycyny. Do ich zadań należy inicjowanie krajowych badań epidemiologicznych oraz ocenianie ich metod i wyników, prognozowanie potrzeb zdrowotnych w swojej dziedzinie, doradzanie, jak realizować zadania, które wynikają z profilaktycznych programów zdrowotnych [35]. W sprawach dotyczących COVID-19 przedstawiciele przynajmniej następujących specjalności mogą być brani pod uwagę: choroby płuc, choroby zakaźne, epidemiologia, intensywna terapia, zdrowie publiczne, zdrowie środowiskowe. Wypowiedzi osób pełniących formalnie funkcję specjalisty były traktowane jako wypowiedzi eksperckie. Rzeczywistość zarządzania i radzenia z kryzysem ujawniła, że przedstawiciele także innych instytucji przyjęli na siebie role eksperckie. W takiej pozycji znaleźli się, dzięki własnej aktywności medialnej, między innymi Paweł Grzesiowski - dyrektor Centrum Medycyny Zapobiegawczej i Rehabilitacji w Warszawie i prezes Fundacji Instytut Profilaktyki Zakażeń, Krzysztof Simon - ordynator oddziału zakaźnego jednego ze szpitali uniwersyteckich, Robert Flisiak prezes Polskiego Towarzystwa Epidemiologów i Lekarzy Chorób Zakaźnych oraz Włodzimierz Gut - biolog, specjalista $\mathrm{w}$ zakresie mikrobiologii i wirusologii, emerytowany już pracownik naukowy NIZP PZH - PIB, a od marca 2020 roku również jeden $\mathrm{z}$ głównych doradców Głównego Inspektora Sanitarnego.

Odziedziczona po czasie przedepidemicznym formalizacja stanowisk doradczych nie ułatwiała - przez pewien przynajmniej czas - identyfikowania wypowiedzi poszczególnych podmiotów jako eksperckich vs. politycznych. Było to następstwem niejasności co do ról, w jakich występowały poszczególne osoby. Dotyczyło to między innymi ministra zdrowia Łukasza Szumowskiego, kardiologa i profesora medycyny, który przez kilka miesięcy starał się sprawiać wrażenie fachowca, czasowo bowiem pełnił tę funkcję. Wrażenie profesjonalnej kompetencji i niezależności było kreowane nie tylko przez samego Szumowskiego, ale także przez otoczenie, co osiągnęło kulminację, gdy to ministrowi pozostawiono prawo rozstrzygnięcia decyzji o terminie mających odbyć się wyborów prezydenckich - na podstawie kryteriów medycznych $[36]^{5}$. Opinia była potrzebna w związku z kontrowersją dotyczącą terminu przeprowadzenia wyborów: partia rządząca utrzymywała termin 10 maja 2020 roku, opozycja natomiast domagała się ich odłożenia z powodu epidemii [37]. Swoisty certyfikat fachowości został wydany ministrowi przez prezydenta Andrzeja Dudę, który powiedział, że „,bardziej ufa fachowcowi niż politykom" [38]. Do prasy przeniknęły jednak niepotwierdzone wiadomości o naciskach wywieranych przez ubiegającego się o reelekcję prezydenta na ministra Szumowskiego, aby zgodził się na termin majowy [39]. Rekomendacja została przedstawiona 17 kwietnia 2020 roku i jej esencją było stwierdzenie, że „nie ma bezpiecznej metody wyboru prezydenta w czasach epidemii w formie tradycyjnej", ale jednocześnie ,jedyną formą, jaką mogę rekomendować jako minister zdrowia, $\mathrm{z}$ punktu widzenia medycznego, są wybory korespondencyjne, bo one minimalizują kontakt międzyludzki i ryzyko związane z transmisją wirusa" [40]. Kiedy parlament podjął decyzję o przeprowadzeniu wyborów, minister wygłosił apel zachęcający do wzięcia w nich udziału, oceniając je jako przedsięwzięcie bezpieczne $[41]^{6}$.

Równie kłopotliwe okazały się próby zakwalifikowania osoby pełniącej funkcję Głównego Inspektora Sanitarnego (GIS). Już samo prawne umocowanie tego stanowiska nie jest jednoznaczne, bo z jednej strony jest to stanowisko rządowe, co nadaje mu niekwestionowany charakter polityczny, ale jednocześnie jego sprawowanie jest związane $\mathrm{z}$ intensywnym wykorzystywaniem wiedzy profesjonalnej. W przypadku Jarosława Pinkasa problem był jeszcze bardziej złożony, ponieważ podczas pełnienia funkcji GIS był on jednocześnie konsultantem krajowym w zakresie zdrowia publicznego [42]. Mając formalne kwalifikacje, by być traktowanym jako ekspert powołany na stanowisko Głównego Inspektora Sanitarnego, pełnił wcześniej funkcję podsekretarza stanu w Ministerstwie Zdrowia (MZ), sekretarza stanu w Ministerstwie Zdrowia, sekretarza stanu w Kancelarii Premiera, co miało miejsce w czasie rządów obecnej większości parlamentarnej [43]. Można zatem uznać, że polityczne afiliacje inspektora były i są na tyle silne, by dawać podstawę do traktowaniu go jako polityka, a nie eksperta.

W gronie osób uznanych za ekspertów warto zwrócić także uwagę na Andrzeja Sośnierza - byłego prezesa Narodowego Funduszu Zdrowia (NFZ), a wcześniej dyrektora Śląskiej Kasy Chorych, gdzie zasłużył się wprowadzeniem elektronicznej karty pacjenta, który obecnie jest posłem jednej z partii wchodzących w skład koalicji rządowej. Mimo oczywistej pozycji politycznej i związanego z tym wymogu politycznej lojalności Sośnierz wielokrotnie krytykował decyzje i działania podejmowane przez ministra zdrowia i innych polityków rządowych.

Za ważnego eksperta $\mathrm{w}$ tej sprawie uznać należy także epidemiologa Andrzeja Horbana, który jest specjalistą chorób wewnętrznych oraz chorób zakaźnych i pełni funkcję krajowego konsultanta w tej dziedzinie. W październiku 2020 roku został głównym doradcą premiera do spraw COVID-19, a następnie 
przewodniczącym Rady Medycznej, powołanej 9 listopada 2020 roku [44]. Epidemiolog dość optymistycznie wypowiadał się na temat sytuacji pandemii COVID-19, zwracając uwagę na pozytywne strony walki z nią. Podkreślał, że pomimo nowej jednostki chorobowej, na którą żaden kraj nie był przygotowany, potrafiliśmy sobie $\mathrm{w}$ pewien sposób $\mathrm{z}$ nią poradzić. Zwracał uwagę na to, że część populacji już przebyła chorobę oraz na fakt dostępu do szczepionek. Według Andrzeja Horbana zachęty kierowane do społeczeństwa w sprawie szczepień ochronnych powinny być budowane na rzetelnych informacjach przekazywanych do wiadomości publicznej [45].

Charakterystyczną cechą polskich ekspertów była daleko idąca przewidywalność przedstawianych przez nich opinii. Pozwala to na odróżnienie osób identyfikujących się zasadniczo z postępowaniem władz, co w znacznym stopniu polegało na poszukiwaniu naukowo popieranych uzasadnień podejmowanych decyzji oraz grupy osób dążących do zachowania neutralności, co w wielu przypadkach musiało prowadzić do opinii krytycznych.

\section{Polskie zespoły doradcze ds. Koronawirtusa}

Trudności w identyfikowaniu ekspertów pogłębiał fakt późnego utworzenia sztabu kryzysowego, który miał uczestniczyć w merytorycznym przygotowywaniu decyzji dotyczących pandemii. Częściowo - być może - działo się tak z powodu zamazania granicy między polityczną i ekspercką rolą ministra zdrowia i GIS, ale nie można wykluczyć organizatorskiego zaniedbania. Z braku wyspecjalizowanego gremium przygotowywanie i podejmowanie decyzji na temat COVID-19 odbywało się w ustalonych instytucjach - w Rządowym Zespole Zarządzania Kryzysowego [46]. To tam podjęto decyzję o wprowadzeniu pierwszych ograniczeń ruchu granicznego [47], na tym forum przedstawiano dane o sytuacji epidemicznej [48], tam analizowano warianty możliwych do wprowadzenia restrykcji będących odpowiedzią na wzrost liczby nowych infekcji [49], ale żadnej z osób, biorących udział w rutynowych spotkaniach, nie można było przypisać statusu eksperta.

Wbrew oczekiwaniom pierwsza grupa doradcza nie została powołana w Ministerstwie Zdrowia, ale w Ministerstwie Nauki i Szkolnictwa Wyższego (MNiSW) [50]. Jednym $z$ jej celów było przygotowywanie i przedstawianie ministrowi informacji o sytuacji epidemicznej wywołanej zachorowaniami na COVID-19 i rekomendacji w tym zakresie. Kilka dni później podobny zespół został utworzony w Ministerstwie Klimatu [51].

Nie wcześniej niż pod koniec maja 2020 roku upubliczniono listę ekspertów doradzających Ministerstwu Zdrowia w sprawach epidemii koronawirusa [52]. W gronie osób wskazanych znalazło się kilkoro pracowników NIZP PZH - PIB, kilkoro członków wielodyscyplinarnego zespołu MOdelling COronavirus Spread (MOCOS), kilkoro pracowników wyższych uczelni. Nie było wśród nich nikogo spośród specjalistów krajowych. Brakowało także informacji o strukturze i zasadach pracy grupy oraz o kompetencjach zaliczonych do niej osób.
Prezes Polskiej Akademii Nauk (PAN) powołał zespół doradczy ds. COVID-19 pod koniec czerwca 2020 roku [53]. W jego skład weszli wysokiej klasy badacze, reprezentujący różne dyscypliny - od biochemii, przez epidemiologię, do socjologii. Od zespołu oczekiwano działań monitorujących przebieg epidemii w Polsce, analizy możliwych scenariuszy reagowania na zagrożenia, formułowania stosownych zaleceń oraz nawiązania współpracy $\mathrm{z}$ podobnymi grupami na świecie. Uznano - jak się wydaje - że autorytet PAN to dostatecznie silny argument przemawiający za wykorzystywaniem przygotowywanych przez zespół rekomendacji.

20 lipca 2020 roku minister zdrowia wydał zarządzenie powołujące Zespół do spraw strategii działań związanych ze zwalczaniem epidemii COVID-19 [54]. W jego skład, poza reprezentantami rządu i Ministerstwa Zdrowia, weszli między innymi przedstawiciele NIZP PZH - PIB, Głównego Inspektoratu Sanitarnego, Agencji Oceny Technologii Medycznych i Taryfikacji (AOTMiT), NFZ, a także krajowi konsultanci w dziedzinie chorób zakaźnych, anestezjologii i intensywnej terapii, medycyny rodzinnej. Wśród nominatów nie było osób przedstawionych na wspomnianej wcześniej imiennej liście badaczy doradzających Ministerstwu [55] $]^{7}$. Aktywność zespołu miała kończyć się sprawozdaniem, trwać do 30 września 2020 roku, po czym zespół miał być rozwiązany. Jednak już po kilku dniach zarządzenie zostało zmienione [56]. Do składu zespołu dołączono przedstawiciela Ministerstwa Obrony Narodowej (MON) oraz zrezygnowano z określenia czasu, na jaki zespół został powołany.

Pod koniec sierpnia 2020 roku stanowisko Ministra Zdrowia objął Adam Niedzielski. Nowy minister zdrowia zarządzeniami z 2 września 2020 roku [57] oraz z 4 września 2020 roku [58] powołał dwa zespoły mające wspierać Ministerstwo w walce $\mathrm{z}$ epidemią COVID-19. Jako pierwszy powołany został Zespół do spraw monitorowania i prognozowania przebiegu epidemii COVID-19, który miał być odpowiedzialny za opracowanie wskaźników i cotygodniowych raportów dotyczących aktualnego i przewidywanego przebiegu epidemii COVID-19 oraz propozycji uproszczenia i usystematyzowania sprawozdawania danych epidemiologicznych. Zespołowi przewodniczył Grzegorz Juszczyk, dyrektor NIZP PZH - PIB, a na jego zastępcę mianowano Pawła Maryniaka, zastępcę dyrektora Departamentu Analiz i Strategii w Ministerstwie Zdrowia. Wśród pozostałych członków zespołu znaleźli się przedstawiciele: Departamentu Analiz i Strategii w MZ, NIZP PZH - PIB, GIS, Głównego Urzędu Statystycznego (GUS), AOTMiT oraz Centrum e-Zdrowia.

Jako drugi powołano Zespół do spraw działań związanych z zapobieganiem, przeciwdziałaniem i zwalczaniem COVID-19, nazwany Sztabem Kryzysowym, w skład którego wchodzili między innymi Główny Inspektor Sanitarny, Prezes NFZ, Dyrektor NIZP PZH - PIB, konsultant krajowy w dziedzinie chorób zakaźnych oraz przedstawiciele różnych komórek organizacyjnych Ministerstwa Zdrowia. Zadaniem Sztabu było analizowanie aktualnej sytuacji epidemiologicznej w Polsce i innych 
krajach, ustalenie rozwiązań mających na celu zapobieganie, przeciwdziałanie i zwalczanie COVID-19 oraz kontynuacja działań zapoczątkowanych przez Zespół do spraw opracowania strategii działań związanych ze zwalczaniem epidemii COVID-19.

\section{Polscy politycy}

Łukasza Szumowskiego ze względu na wykształcenie i pełnioną funkcję w rządzie można było zakwalifikować zarówno do grupy ekspertów, jak i do polityków. W obliczu epidemii oczekiwano, że będzie on raczej pełnił funkcję eksperta, jednak częściej przyjmował role polityka, zwłaszcza w kwestii wyborów prezydenckich. Do głównych zarzutów kierowanych w stronę byłego ministra zdrowia zaliczyć można niekonsekwencje, brak jednolitej strategii walki z epidemią koronawirusa oraz brak reakcji na tezy, które bez podstaw naukowych były wygłaszane publicznie przez innych polityków. Z dniem 9 sierpnia 2020 roku Łukasz Szumowski przestał pełnić funkcję ministra zdrowia, składając swoją rezygnację z tego stanowiska [59]. Jego zastępcą został ekonomista i były prezes NFZ - Adam Niedzielski [60].

Nowego ministra zdrowia nie można zatem uznać za eksperta w dziedzinie zdrowia populacyjnego, gdyż specjalizuje się on w naukach ekonomicznych i w zarządzaniu strategicznym. Zagadnienia związane ze zdrowiem rozpatruje on $\mathrm{w}$ kategoriach budowania kapitału ludzkiego, stanowiącego fundamentalny czynnik wzrostu gospodarczego, a konsekwencji jego braku upatruje nie tylko w skutkach zdrowotnych społeczeństwa, ale także jako szkody dla gospodarki w postaci między innymi absencji chorobowych. To spojrzenie na zdrowie publiczne różni się od poglądów poprzednich ministrów, którzy z reguły byli ekspertami z dziedziny medycyny i nauk o zdrowiu ${ }^{8}$. Adam Niedzielski jeszcze przed objęciem stanowiska zapowiadał, że jego przesłaniem będzie hasło „Wszystkie ręce na pokład”. Działania w walce z epidemią miał opierać na dialogu, otwartości i współpracy [61].

Zachodzące zmiany można było także zauważyć w urzędzie GIS, gdzie 20 listopada 2020 roku Jarosław Pinkas ze względów zdrowotnych podjął decyzję o rezygnacji ze stanowiska Głównego Inspektora Sanitarnego. Niedzielski ogłosił jednak, że w najbliższym czasie nie planuje ogłaszać konkursu na to stanowisko. Swoją decyzję w tej sprawie motywował tym, że urząd mierzy się obecnie z innymi problemami, które należy rozwiązać w pierwszej kolejności. Głównego Inspektora Sanitarnego zastępuje - Krzysztof Saczka, który nie może objąć tego stanowiska, gdyż nie spełnia wymogów prawnych - nie jest lekarzem [62].

Politykiem, który równie często zabierał głos w wystąpieniach publicznych w sprawie pandemii COVID-19 i związanej z nią sytuacji w kraju, był premier Mateusz Morawiecki. Prezes Rady Ministrów przed drugą turą wyborów prezydenckich publicznie oświadczał, że wirus jest już w odwrocie i nie trzeba się go dłużej obawiać. Apelował, aby ,pójść tłumnie do urn wyborczych", a słowa te kierował zwłaszcza do seniorów. Wchodząc w rolę eksperta, twierdził, że: „latem wirusy grypy i ten koronawirus są słabsze, dużo słabsze" [63]. Oświadczenia te nie były poparte żadnymi dowodami naukowymi, miały one na celu zachęcenie wyborców do udziału w drugiej turze wyborów organizowanych w lipcu 2020 roku W tym samym czasie Tedros Adhanom Ghebreyesus, dyrektor generalny Światowej Organizacji Zdrowia, stwierdził, że ,pandemia COVID-19 nawet nie zbliża się jeszcze do końca”. Szef WHO uznał, że pandemia wciąż stanowi zagrożenie, a większość ludzi jest nadal podatna na wirusa, który wciąż może się rozwijać [64].

\section{Plaszczyzny podobieństw i różnic}

Między Polską a Stanami Zjednoczonymi można zauważyć wiele podobieństw i różnic w działaniach podejmowanych $\mathrm{w}$ walce $\mathrm{z}$ pandemią wirusa SARS-CoV-2, co zostało zebrane $\mathrm{w}$ tabeli 1 . Te pierwsze przejawiały się zarówno w decyzjach, jak i stanowiskach przyjmowanych przez polityków obu krajów oraz sposobie i treściach komunikatów udostępnianych do publicznej wiadomości. Również w przypadku polskich i amerykańskich ekspertów oraz ich opinii doradczych można doszukać się pewnych analogii. Nie zawsze jednak strategia walki z wirusem i relacje między politykami a ekspertami w analizowanych krajach były takie same.

Kryterium 1: Wobec braku skutecznych procedur medycznych, które mogłyby chronić przed infekcją, jedyną metodą racjonalnej reakcji na epidemię ze strony zdrowia publicznego były różne ograniczenia kontaktów międzyludzkich. Władze wprowadzały te ograniczenia uznając, że zdrowie jest wartością - w tej sytuacji - nadrzędną wobec aktywności gospodarczej. Jednak wszędzie po okresie restrykcji konieczna była rezygnacja z ograniczeń.

W USA widoczne jest jasne i jednolite stanowisko ekspertów rekomendujących na początku epidemii raczej surowe ograniczenia, stosowane na szeroką skalę, a następnie ostrożną liberalizację, realizowaną w zależności od rozwoju sytuacji epidemicznej (publicznie żaden ekspert nie wycofał się ze swojego stanowiska). Po stronie polityków na początku epidemii była akceptacja rygorystycznych ograniczeń, a po pewnym czasie pojawiła się wyraźna skłonność do traktowania otwarcia gospodarki i powrotu do aktywności ekonomicznej jako priorytetu. Wyraźny jest podział ról między ekspertami i politykami.

W Polsce widoczne jest stanowisko ekspertów popierające restrykcje i nawołujące do ostrożności, ale mniej zdecydowanie i mniej jednolicie niż w USA. Pojawia się zatarcie granicy między rolą eksperta i rolą polityka (minister zdrowia). Wiele komunikatów wymagających wiedzy eksperckiej przedstawianych jest przez polityków. Widoczna jest wyraźna zmiana (fluktuacja) stanowiska polityków, przejawiająca się w fazie pierwszej - lekceważeniem zagrożenia, w fazie drugiej - drastycznymi restrykcjami, często nieuzasadnionymi, w fazie trzeciej - zadekretowaniem poprawy sytuacji i decyzjami o liberalizacji, bez wskazania kryteriów podejmowanych decyzji. 
Kryterium 2: Systemy zdrowotne obydwu krajów okazały się w znacznym stopniu nieprzygotowane do stawienia czoła epidemii, zwłaszcza na polu medycznej reakcji na ciężkie zachorowania. Chodziło zarówno o wyposażenie oddziałów ratunkowych (respiratory), jak i sprzęt ochrony osobistej (maseczki, gogle, fartuchy). W tych warunkach niezbędne stawało się otwarcie możliwości podejmowania szybkich decyzji o pozyskiwaniu i zakupie niezbędnego sprzętu.

W USA prezydent przypisał sobie prawo motywowania przedstawicieli przemysłu do podejmowania decyzji o uruchamianiu produkcji wskazanego przez niego sprzętu. Działał tak, jakby oczywista w rynkowej gospodarce zasada niezależności podmiotów gospodarczych przestała obowiązywać.

W Polsce działano dwutorowo. Po pierwsze, tworzono preferencyjne warunki wytwarzania potrzebnych artykułów spółkom skarbu państwa (np. zwolnienie z podatku spirytusu przetwarzanego na płyn dezynfekujący przez państwową spółkę). Po drugie, osłabiono rygoryzm reguł, które administracja państwowa powinna stosować przy zakupach (zwykle są to przetargi, w których biorą udział sprawdzeni sprzedawcy). W warunkach epidemii administracja mogła kupować wszystko od wszystkich i była zwolniona $\mathrm{z}$ odpowiedzialności karnej. W efekcie Ministerstwo Zdrowia kupiło wadliwy sprzęt i to zarówno od krajowych, jak i zagranicznych kontrahentów.

Kryterium 3: Jedną z ważnych metod ograniczających, a przynajmniej zwalniających rozprzestrzenianie się wirusa było stosowanie maseczek i jest oczywiste, że poglądy na temat ich stosowania mogą być różne.

W USA stanowisko ekspertów w tej sprawie było jednolite i niezmienne; jednoznacznie zalecano stosowanie maseczek. Prezydent zmieniał zdanie. Początkowo twierdził, że maseczki są mało przydatne i są zbędnym utrudnieniem codziennego życia. Po jakimś czasie uznał przydatność maseczek, ale jednocześnie zadeklarował, że sam maseczek używać nie będzie. Po kilku miesiącach - w lipcu - stwierdził jednak, że w obliczu ponownego wzrostu liczby zachorowań maseczki powinny być stosowane, a kiedy pojawił się w miejscu publicznym w maseczce fakt ten został zauważony przez media jako wydarzenie.

W Polsce stanowisko ekspertów nie było jednolite. W początkowej fazie epidemii niektórzy z nich, pełniący ważne funkcje doradcze w rządzie, wypowiadali się bardzo sceptycznie o przydatności maseczek, akcentując w publicznym przekazie potencjalne zagrożenie wynikające $\mathrm{z}$ ich stosowania. Była jednak także grupa ekspertów - nazywamy ich niezależnymi - którzy konsekwentnie zalecali stosowanie maseczek. Minister zdrowia zmieniał zdanie: początkowo o maseczkach wyrażał się z rezerwą, później uznał, że noszenie maseczek jest niezbędne i przeforsował obowiązek ich powszechnego stosowania w miejscach publicznych, handlu, transporcie itd. [65].

Kryterium 4: Znane jest wezwanie WHO ogłoszone na początku pandemii: „testujcie, testujcie, testujcie”, co miało być powszechnie stosowaną metodą aktywnego zwalczania epidemii.
W USA stanowisko ekspertów w tej sprawie było jednolite i jednoznaczne: należy wykonywać możliwie dużo testów (na obecność wirusa) i śledzić drogi zakażania kolejnych osób. Stanowisko prezydenta Trumpa było odmienne: kilkakrotnie potwierdzał, że utrzymująca się duża liczba nowych zachorowań w ciągu kolejnych dób jest związana z przeprowadzaniem dużej liczby testów. Z opinii takich wynikało, że ograniczenie testowania doprowadzi do zmniejszenia liczby osób zainfekowanych. Prezydent nie dodawał, że w ten sposób zmniejsza się liczba przypadków potwierdzonych, a nie liczba zachorowań rzeczywistych.

W Polsce stanowisko ekspertów nie było jednolite. Część ekspertów niezależnych jednoznacznie apelowała do władz o zwiększanie liczby przeprowadzanych testów, także do szybszego uzyskiwania wyników. Argumentowali, że brak wiedzy na temat liczby rzeczywistych zachorowań uniemożliwia oszacowanie rozmiarów epidemii, utrudniając racjonalne reagowanie ze strony systemu zdrowotnego. Natomiast część ekspertów związana z władzą broniła małej liczby testów, ograniczając ich stosowanie jedynie do osób z symptomami COVID-19, i argument bardzo wysokiego odsetka zachorowań bezobjawowych nie był przez nich brany pod uwagę. Politycy niezmiennie stali na stanowisku, że testy powinny być stosowane wyłącznie wobec osób kwalifikowanych do badań na podstawie wskazanych kryteriów: były to symptomy charakterystyczne dla infekcji, jak wysoka temperatura, kaszel, ból gardła, trudności w oddychaniu. Decyzja o skierowaniu na badania ze względu na wskazania epidemiologiczne, np. przy powrocie z zagranicy czy kontakcie $\mathrm{z}$ chorym, pozostawała w gestii pracowników Inspekcji Sanitarnej. Możliwość kontaktu z osobami zainfekowanymi - np. pobyt we Włoszech - była wskazaniem do kwarantanny, ale nie do testów. Zasady ograniczania testów uderzały w lekarzy i innych pracowników medycznych opiekujących się osobami zarażonymi koronawirusem: władza odmówiła stosowania regularnych i bezpłatnych testów tej grupy pracowników. Jednocześnie możliwość skorzystania z odpłatnych testów o certyfikowanej wartości (czułość, swoistość) była bardzo ograniczona.

Kryterium 5: Jednym z elementów liberalizacji była decyzja o powrocie do rutynowego nauczania szkolnego po okresie zamknięcia szkół.

W USA eksperci rekomendowali ostrożny powrót do szkół z początkiem nowego roku szkolnego. CDC opublikowało rekomendacje, w których wskazano wiele działań służących zachowaniu reguł ostrożności sanitarnej. Prezydent jednoznacznie opowiadał się za rozpoczęciem zajęć szkolnych w rutynowej postaci. Rekomendacje CDC określił jako przesadne i kosztowne. Zagroził cofnięciem dotacji rządowych dla szkół, w których zajęcia nie byłyby podjęte (absurdalność tej groźby wynikała z dwóch powodów - po pierwsze, odpowiedzialność za oświatę spoczywa na rządach stanowych; po drugie, szkoły są finansowane przez stany i społeczności lokalne). Nauczycielskie związki zawodowe nawoływały do ostrożności, zwracając uwagę na bezpieczeństwo zarówno uczniów, jak i nauczycieli. 


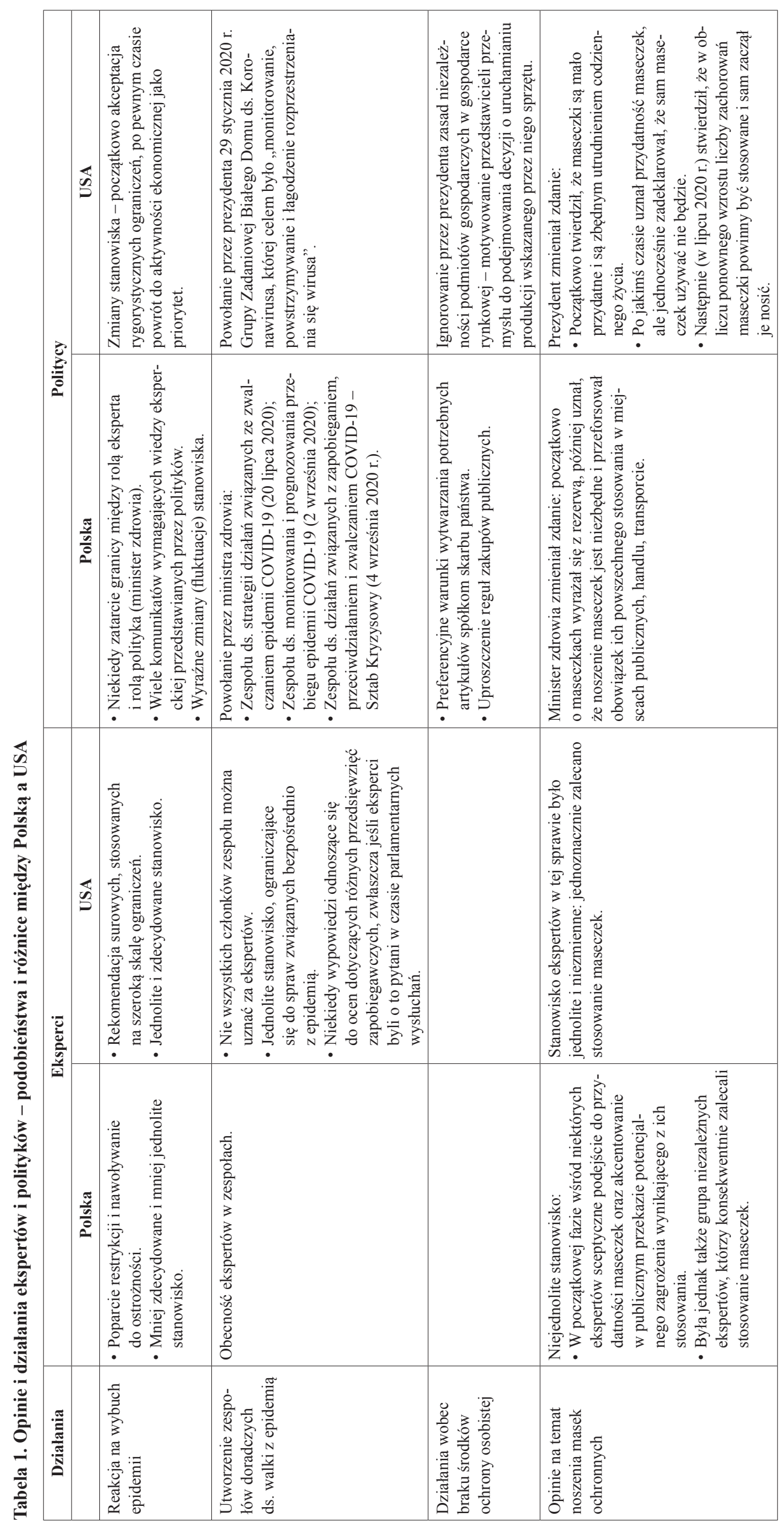




\begin{tabular}{|c|c|c|c|c|}
\hline \multirow{2}{*}{ 胥 } & 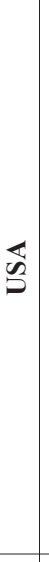 & 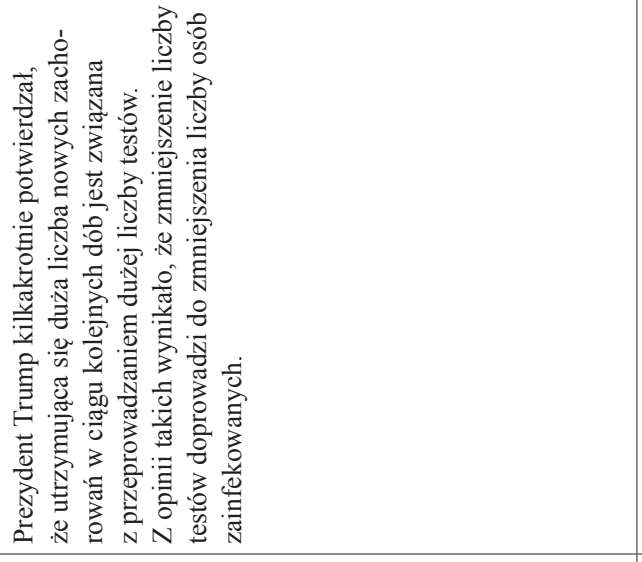 & 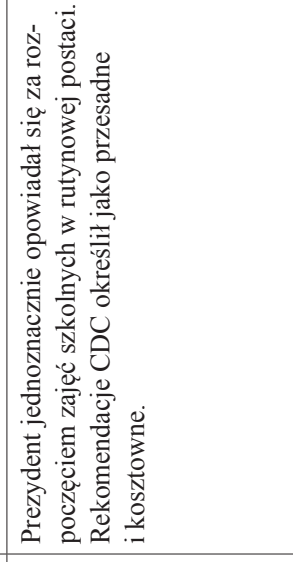 & 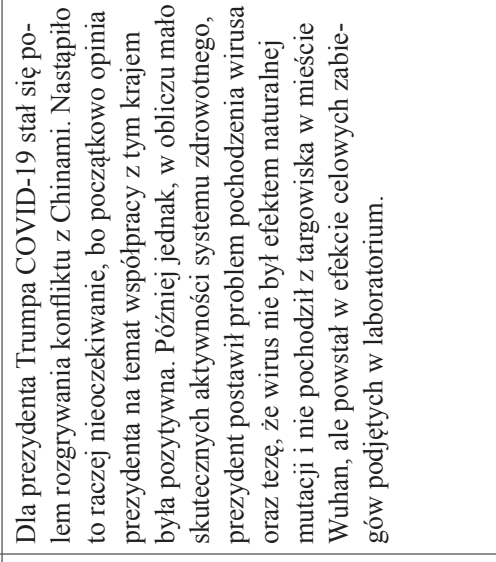 \\
\hline & 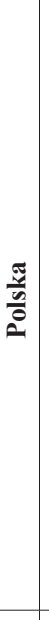 & 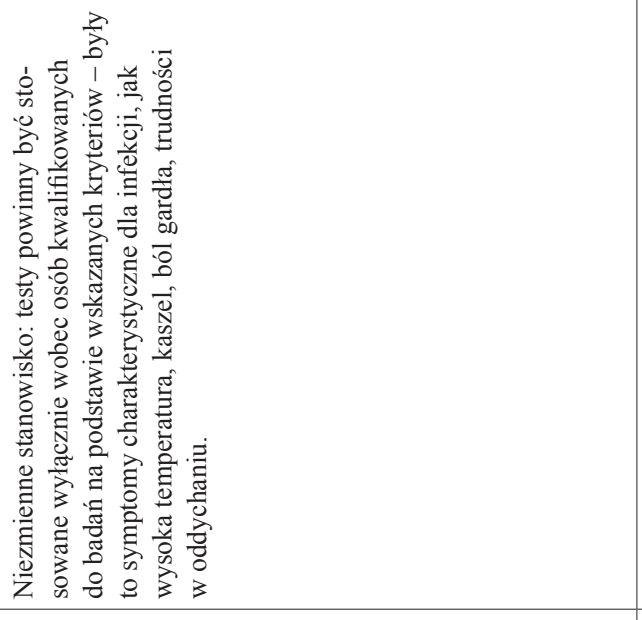 & 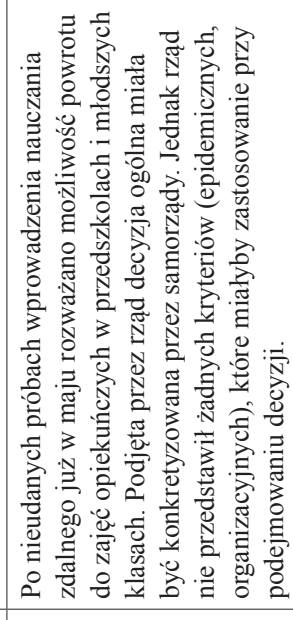 & 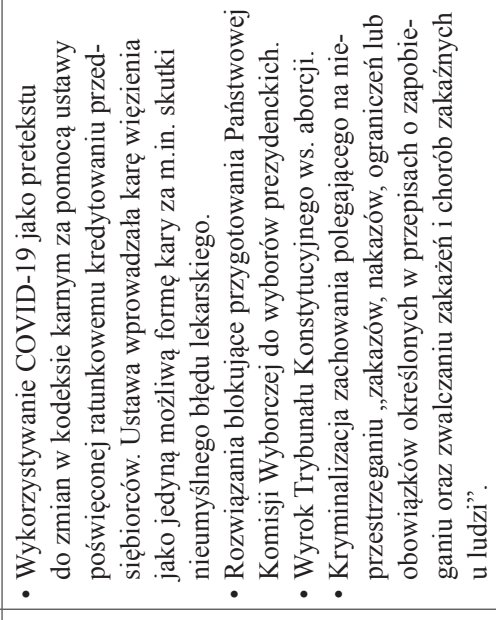 \\
\hline \multirow{2}{*}{ 宽 } & 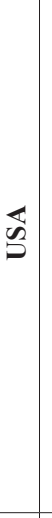 & 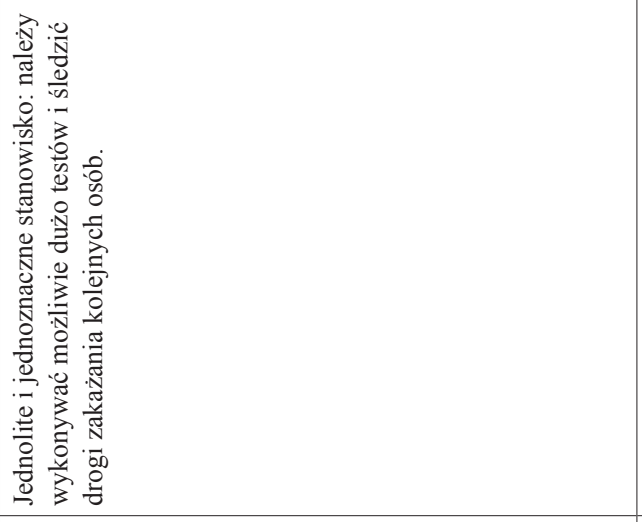 & 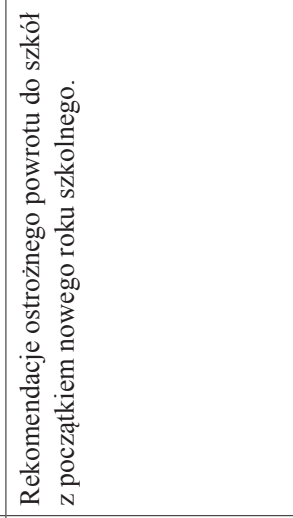 & \\
\hline & & 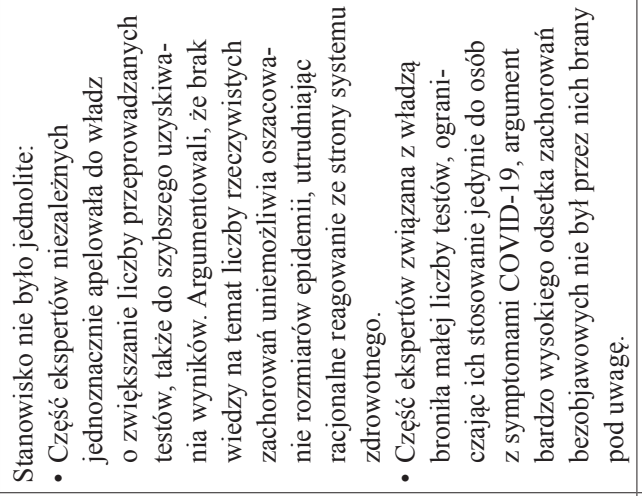 & 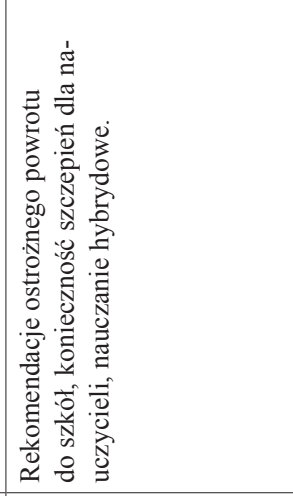 & \\
\hline & & 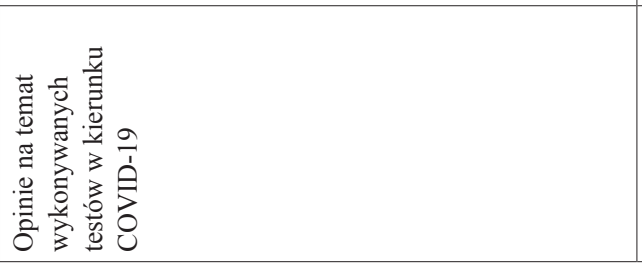 & 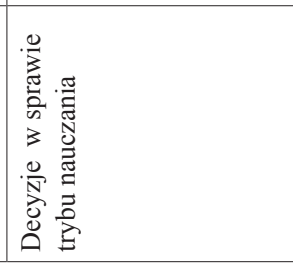 & 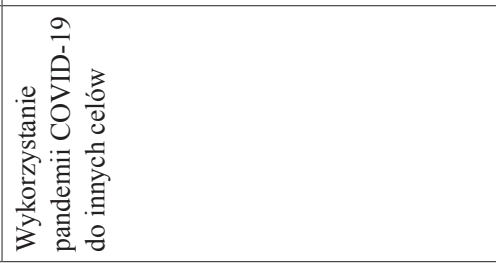 \\
\hline
\end{tabular}


W Polsce po nieudanych próbach wprowadzenia nauczania zdalnego, już w maju rozważano możliwość powrotu do zajęć opiekuńczych w przedszkolach i młodszych klasach. Podjęta przez rząd decyzja ogólna miała być konkretyzowana przez samorządy. Jednak rząd nie przedstawił żadnych kryteriów (epidemicznych, organizacyjnych), które miałyby zastosowanie przy podejmowaniu decyzji. Rząd nie podją także decyzji o badaniu nauczycieli i wychowawców na obecność wirusa albo obecność przeciwciał. Co więcej, kiedy samorządy podejmowały decyzje o prowadzeniu takich badań, musiały finansować je z własnych środków, ponieważ rząd nie był zainteresowany wynikami tych badań i w konsekwencji nie chciał ich finansować. Po wakacjach dzieci wróciły do szkół zaledwie na kilka tygodni, tym razem decyzja o ich zamknięciu zapadła szybko. Po praktycznie całym roku szkolnym w trybie zdalnym Ministerstwo Edukacji i Nauki (MEiN) zapowiedziało otwarcie szkół na cztery ostatnie tygodnie, sugerując że powinien być to czas odbudowy relacji z rówieśnikami, odbudowy poczucia wspólnoty [66] ${ }^{10}$.

Kryterium 6: Zagrożenie pandemią dawało politykom możliwości jego wykorzystywania do uzasadniania działań, które w innych okolicznościach nie byłyby łatwo akceptowane przez wielu ludzi. Najważniejszym i najbardziej widocznym takim działaniem było wprowadzanie lockdownu, ograniczającego w szerokim zakresie społeczne kontakty i aktywności. O ile jednak lockdown miał, zwłaszcza we wczesnych fazach pandemii, racjonalne uzasadnienie, o tyle wiele innych inicjatyw takiego uzasadnienia nie miało.

Dla prezydenta Trumpa problem COVID-19 stał się polem rozgrywania konfliktu z Chinami. Nastąpiło to raczej nieoczekiwanie, bo początkowo opinia prezydenta na temat współpracy z tym krajem była pozytywna. Później jednak, w obliczu mało skutecznych aktywności systemu zdrowotnego, prezydent postawił tezę, że wirus nie był efektem naturalnej mutacji i nie pochodził $\mathrm{z}$ targowiska w mieście Wuhan, ale powstał w efekcie celowych zabiegów podjętych w laboratorium. Prezydent, a także Sekretarz Stanu twierdzili, że mają na to dowody, mimo odmiennej opinii przedstawianej przez wywiad. Konsekwencją tezy o celowo szkodliwym działaniu Chin była decyzja o wystąpieniu z WHO pod pretekstem, że ta organizacja ulega chińskiej manipulacji.

W Polsce pod pretekstem zapewnienia funkcjonowania państwa w warunkach pandemii oraz stworzenia systemu pomocy dla tych, którzy w jej wyniku utracili możliwość zarobkowania (tzw. tarcze antykryzysowe) wprowadzano kontrowersyjne zmiany np. w Kodeksie wyborczym czy prawie karnym. W jednej z tarcz antykryzysowych znalazły się regulacje odnoszące się do zasad wymiaru kary łącznej, sankcji grożącej za czyn ciągły czy kryminalizacji kradzieży szczególnie zuchwałej; w innej - wprowadzono rozwiązania blokujące przygotowania Państwowej Komisji Wyborczej do wyborów prezydenckich. W duchu ograniczania transmisji koronawirusa SARS-CoV-2 nakazano pracę profesjonalistów medycznych: lekarzy, pielęgniarek, pielęgniarzy, ratowników medycznych tylko w jednym podmiocie leczniczym [67], jednak szybko się z tego wycofano, pozostawiając decyzję o takim ograniczeniu dyrekcji placówki [68]. Przykładem wykorzystywania COVID-19 jako pretekstu była zmiana kodeksu karnego przy pomocy ustawy poświęconej ratunkowemu kredytowaniu przedsiębiorców. Ustawa wprowadzała karę więzienia jako jedyną możliwą formę kary za między innymi skutki nieumyślnego błędu lekarskiego. Poprzednio była możliwość kary grzywny lub ograniczania wolności. Pod pretekstem walki z koronawirusem próbowano wprowadzić także tzw. ustawę o bezkarności, która zakładała, że naruszenie obowiązków służbowych lub innych przepisów przez osobę działającą na rzecz zapobiegania oraz zwalczania COVID-19 nie byłoby traktowane jako przestępstwo. Brak zgody wewnątrz koalicji rządzącej doprowadził jednak do tymczasowego wycofania projektu [69]. Warto wspomnieć również o wyroku Trybunału Konstytucyjnego ws. aborcji, który został wydany w czasie, w którym obowiązywał zakaz zgromadzeń, a pandemia wkraczała $\mathrm{w}$ trzecią falę ${ }^{11}$. W nowelizacji Kodeksu wykroczeń (art. 116) z 28 października 2020 roku zdecydowano się na kryminalizację zachowania polegającego na nieprzestrzeganiu ,zakazów, nakazów, ograniczeń lub obowiązków określonych w przepisach o zapobieganiu oraz zwalczaniu zakażeń i chorób zakaźnych u ludzi”. W styczniu 2021 roku ogłoszono z kolei poselski projekt nowelizacji Kodeksu postępowania w sprawach o wykroczenia. Zakłada on między innymi, że ukarany mandatem za wykroczenie nie będzie mógł odmówić jego przyjęcia, a jedynie odwołać się do sądu w terminie 7 dni, wskazując w odwołaniu wszystkie znane sobie dowody na poparcie swych twierdzeń, pod rygorem utraty prawa do ich powoływania w dalszym postępowaniu [70].

\section{Rzetelna wiedza a celowa dezinformacja}

Pomimo korzyści płynących ze zwiększonego poziomu przejrzystości procesu decyzyjnego, w szczególności w odniesieniu do opinii naukowych, na których opierają się decyzje, wiele krajów kontrolowało charakter i ilość informacji udostępnianych opinii publicznej. Publikacja zdań odrębnych w ramach naukowych komitetów doradczych jest dość rzadka. Niektóre kraje, takie jak Irlandia, przyjęły niezwykle przejrzyste podejście do porad naukowych dotyczących pandemii. Irlandzki National Public Health Emergency Team (NPHET) jest oficjalnym mechanizmem koordynowania reakcji sektora zdrowia w kraju. Dąży do ułatwienia przepływu informacji między departamentem zdrowia i jego agencjami oraz stanowi forum do budowania konsensusu w sprawie strategicznego podejścia do kryzysu. Porządki obrad i protokoły posiedzeń NPHET - w których znajdują się także zdania odrębne do rządzących - są systematycznie publikowane na stronie internetowej departamentu zdrowia [71].

Przywódcy wielu krajów początkowo nie docenili powagi pandemii, pomimo pogarszającej się sytuacji. W ciągu pierwszych kilku tygodni zauważalny był brak informacji charakteryzujący się niezdolnością lub niechęcią do podania dokładnych informacji o rozprzestrzenianiu 
się wirusa ze strony kilku agencji rządowych. Na przykład Chiny ukryły i ocenzurowały doniesienia lekarzy, którzy jako pierwsi dowiedzieli się o rozprzestrzenianiu się niebezpiecznego nowego wirusa. W tym przypadku chodziło o wolę polityczną, aby nie straszyć ludności i uniknąć konsekwencji gospodarczych (w Wuhan znajdują się ważne firmy produkcyjne, które mają silne relacje handlowe z całym światem) [72]. Rządzący okazali ogólny brak gotowości do zarządzania kryzysem, gdy pandemii nie można było dłużej zaprzeczać ani ukrywać.

Oprócz chęci uniknięcia wywoływania paniki i trudności gospodarczych troską niektórych organów państwowych było pokazanie, że mają pełną kontrolę nad sytuacją, więc nie muszą wprowadzać nadzwyczajnych środków, co świadczy o braku interwencji prewencyjnych. W wielu krajach nie udzielono jednoznacznych porad dotyczących tego, kiedy i jak ograniczyć zgromadzenia, odwołać duże imprezy, odroczyć podróże lub ograniczyć produkcję przemysłową i handel, co znacząco przyczyniło się do rozprzestrzeniania się infekcji. Na przykład Donald Trump odrzucił pandemię, uznając ją za „mistyfikację demokratów" i przewidując, że zniknie ona jak cud. Podobnie prezydent Brazylii Jair Bolsonaro scharakteryzował pandemię koronawirusa jako napędzaną przez media „fantazję” [73]. Z kolei prezydent Filipin Rodrigo Duterte nazwał zmartwionych nowym koronawirusem ,głupcami” i naruszył zasadę ,zakazu dotykania” - oznaczającą, że nikt nie powinien go dotykać podczas imprez publicznych - ściskając ręce kibicom.

W tym samym czasie eksperci medyczni (zwłaszcza wirusolodzy, immunolodzy i epidemiolodzy, ale także statystycy i naukowcy zajmujący się zdrowiem publicznym) zwiększyli swoje zaangażowanie. W przeciwieństwie do polityków i decydentów na różnych szczeblach, którzy od początku pandemii oferowali raczej niejasne i często sprzeczne rady, wielu ekspertów ostrzegało, że epidemia może wybuchnąć i bardzo wcześnie sugerowali wprowadzenie szeregu środków zapobiegawczych (w tym dystans społeczny, zamykanie szkół i uniwersytetów, zakazy dużych zgromadzeń i podróży międzynarodowych, pracę zdalną i izolację), aby zapobiec dalszemu rozprzestrzenianiu się wirusa $[74,75]$.

Początkowe ukrywanie informacji i dezinformacja instytucjonalna przyczyniły się do erozji zaufania społeczeństwa do rządów i instytucji międzynarodowych. Eksperci zaczęli proponować wdrożenie środków w zakresie zdrowia publicznego, aby pomóc obywatelom uniknąć zarażenia, stając się tym samym źródłem dokładnych informacji i rzetelnej polityki zdrowotnej [76]. Ze względu na powagę pandemii i konkretne zagrożenie dla ludności, przy gwałtownym wzroście liczby zakażeń i ofiar, większość populacji polegała na autorytecie ekspertów. W podobnym duchu prawie wszystkie rządy jedne z przekonania, a zatem szybciej, inne z konieczności wkrótce potem - skorzystały z już działających lub powołanych na tę okazję komitetów techniczno-naukowych i powierzyły im identyfikację najbardziej odpowiedniej polityki w zakresie zdrowia publicznego. To przekazanie uprawnień i odpowiedzialności ekspertom pozwoliło przywódcom i rządom zmniejszyć ich własną odpowiedzialność wobec społeczeństwa [77]. W niektórych krajach po początkowym zaufaniu przez rządzących do wiedzy eksperckiej zmieniał się kierunek działań. Przykładowo w połowie kwietnia 2020 roku premier Tanzanii wystosował prosty apel: „Tanzańczycy powinni zachować zaufanie do rządu. Nadal powinieneś ufać naszym ekspertom, którzy stoją za każdą podejmowaną przez nas decyzją". Miesiąc później prezydent kraju zwolnił szefa krajowego laboratorium testowego COVID-19 i zobowiązał się do sprowadzenia niesprawdzonego toniku ziołowego z Madagaskaru, który, mimo obaw naukowców, był kontrowersyjnie reklamowany jako lek na nowego koronawirusa [78].

W ostatnich latach wśród laików pojawiła się powszechna tendencja do dewaluacji wiedzy fachowej. Zdaniem byłego sekretarza stanu ds. sprawiedliwości Michaela Gove'a, Wielka Brytania opuściła Unię Europejską, ponieważ „ludzie w tym kraju mają dość ekspertów" [79]. W USA wyborcy jednoznacznie zlekceważyli opinię ekspertów, wybierając na prezydenta Donalda Trumpa, który wbrew około 99\% konsensusu naukowego zaprzeczał realiom zmian klimatycznych [80]. W wielu krajach poparcie zyskały partie prawicowe, które cieszą się niewielką sympatią ekspertów.

Generalnie można powiedzieć, że medycyna nadal jest jedną z dziedzin, w których ludzie polegają na ekspertach przy podejmowaniu decyzji dotyczących ich zdrowia i bezpieczeństwa. Jednak coraz więcej osób nie wierzy medycznym ekspertom, co przejawia się między innymi w podważaniu skuteczności szczepień (zjawisko to było już widoczne przed pandemią) czy popularności medycyny alternatywnej.

Obecnie kluczowym elementem skutecznego zwalczania pandemii na świecie jest porządek publiczny i obywatelskie posłuszeństwo protokołom. Ludzie muszą więc otrzymywać rzetelne i wiarygodne wiadomości z zaufanych źródeł informacji. Celowa dezinformacja na temat nauki jest szczególnie szkodliwa dla wiarygodności ekspertów dążących do sformułowania odpowiedniej polityki zdrowotnej, ponieważ osłabia zaufanie ludzi do porad ekspertów.

Wyjęcie ,polityki” z procesu podejmowania decyzji administracyjnych ma kluczowe znaczenie nie tylko dla decyzji opartych na dowodach, ale także dla wiarygodności przywódców administracyjnych w czasach, gdy dezinformacja staje się coraz większym problemem publicznym. W odpowiedzi rządu federalnego USA na wybuch epidemii COVID-19 polityka wyborcza w połączeniu z uprzedzeniami poznawczymi dotyczącymi wirusa poważnie podważyły proces decyzyjny oparty na nauce, gdy wybrani urzędnicy mieli predyspozycje do przedkładania wzrostu gospodarczego nad konsekwencje pandemii dla zdrowia i życia ludzi.

\section{Zaufanie społeczeństwa do polityków i ekspertów}

W obliczu zagrożenia, jakim jest pandemia, w społeczeństwie często pojawiają się chaos, niewiedza, a niekiedy panika i strach. W takiej sytuacji ludzie oczekują od władz oraz ekspertów dostępu do sprawdzonych 
i rzetelnych informacji, raportów i danych o sytuacji pandemicznej na świecie. Komunikacja między społeczeństwem a ekspertami i politykami najczęściej odbywa się za pośrednictwem mediów i jest ona kluczowym elementem działań prowadzonych w czasie pandemii. Skuteczna komunikacja pozwala na przekazanie społeczeństwu podjętych i planowanych działań w walce z pandemią, a także wytycznych, zaleceń i nakazów, do których społeczeństwo powinno się stosować, aby nie dopuścić do rozprzestrzenienia się choroby. Komunikacja między władzą, ekspertami a obywatelami danego kraju musi więc opierać się na zaufaniu społeczeństwa do osób, które publicznie wypowiadają się na temat strategii walki z pandemią i przekazują kluczowe zalecenia. Tylko wtedy władze kraju i eksperci będą mogli skutecznie wpływać na zachowania ludności.

Zaufanie społeczne do przedstawicieli środowisk eksperckich i politycznych w świetle pandemii COVID-19 stało się obiektem zainteresowań i badań prowadzonych przez różne instytucje krajowe. W Polsce badanie takie zostało przeprowadzone przez Instytut Badań Rynkowych i Społecznych (IBRIS) na zlecenie gazety „Fakt”. Badanie odbyło się 8 stycznia 2021 roku na ogólnopolskiej próbie 1100 osób [81]. Wyniki zostały zaprezentowane na wykresie 1.

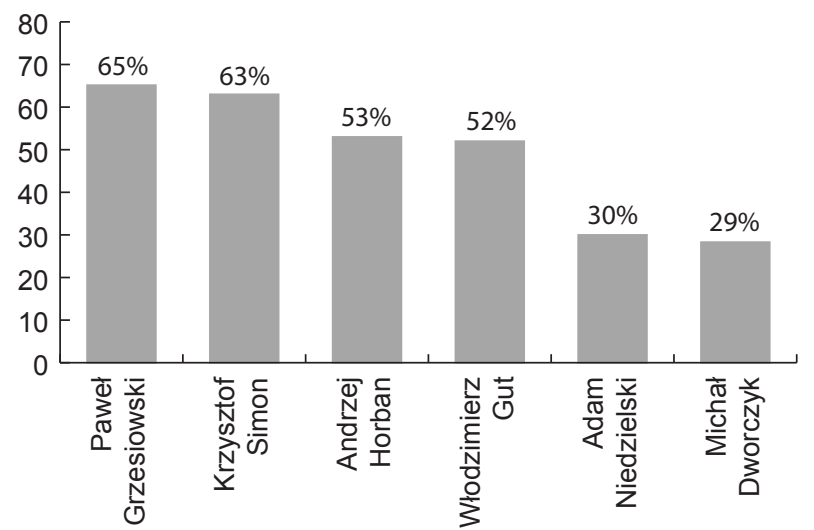

Wykres 1. Deklarowane zaufanie społeczeństwa do wybranych ekspertów i polityków w Polsce

Źródło: opracowanie własne na podstawie [81].

Według powyższych danych Polacy w obliczu pandemii COVID-19 deklarują większe zaufanie do ekspertów niż do polityków. Przedstawicielami środowisk eksperckich w niniejszym badaniu byli: Paweł Grzesiowski (65\%), Krzysztof Simon (63\%), Andrzej Horban (53\%) oraz Włodzimierz Gut (52\%), a wśród reprezentantów polityków znaleźli się obecny minister zdrowia Adam Niedzielski $(30 \%)$ oraz pełnomocnik rządu ds. narodowego programu szczepień ochronnych przeciwko wirusowi SARS-CoV-2 - Michał Dworczyk (29\%). Niskie zaufanie do wybranych polityków pokazuje też nowy (za marzec 2021 roku) ranking zaufania przygotowany przez Centrum Badania Opinii Społecznej (CBOS) [82], w którym minister zdrowia zdobył 32\%, a Dworczyk tylko 21\% zaufania. Wyniki te świadczą jednak o pewnym wzroście zaufania do tych polityków, w rankingu z grudnia 2020 roku Niedzielskiemu ufało bowiem tylko $25 \%$ badanych, a Dworczykowi - 18\% [83].

Warto wspomnieć o zaufaniu, jakim cieszył się były minister zdrowia Łukasz Szumowski. Wraz z pierwszymi przypadkami zachorowań na COVID-19 w Polsce i aktywnością $\mathrm{w}$ mediach notował on ogromny wzrost rozpoznawalności i zaufania. Kolejne miesiące, w których pandemia była tylko jednym z kłopotów szefa resortu zdrowia, drugim - podnoszone przez opozycję zarzuty konfliktu interesów oraz niejasnych powiązań biznesowo-rodzinnych, przyniosły mu wprawdzie dalszy wzrost zaufania (o 7 punktów procentowych), ale i dużo większy w skali wzrost ocen krytycznych. Zmiany w zaufaniu społeczeństwa do byłego ministra zdrowia Łukasza Szumowskiego prezentuje wykres 2 [84-87].

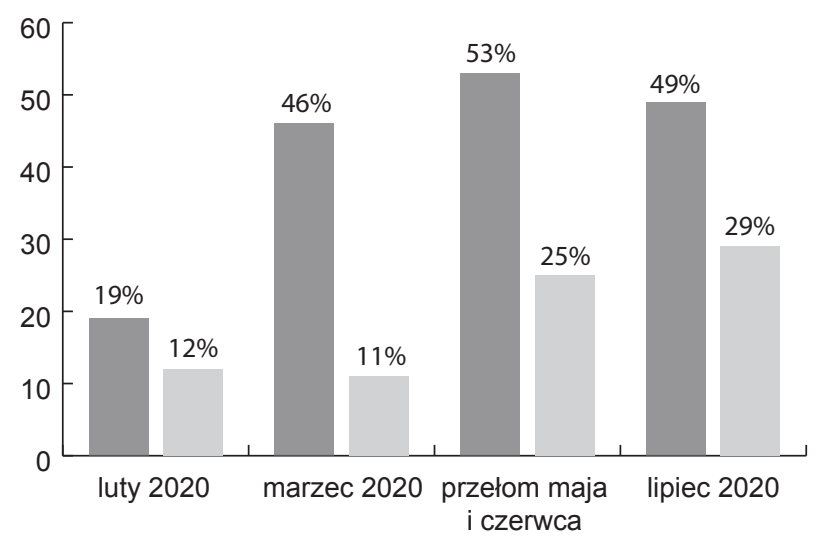

Wykres 2. Zmiany w deklarowanym przez społeczeństwo zaufaniu do byłego ministra zdrowia Lukasza Szumowskiego

Źródto: opracowanie własne na podstawie Komunikat z Badań CBOS, luty 2020 [84], marzec 2020 [85], czerwiec 2020 [86], lipiec 2020 [87].

Podobny sondaż został przeprowadzony w Stanach Zjednoczonych przez „New York Times”/Siena College. W badaniu wzięło udział 1337 zarejestrowanych wyborców w okresie od 17 do 22 czerwca 2020 roku. Pytania zadano połowie respondentów (646), ponieważ nie uwzględniono osób, które nie identyfikowały się z jakąś partią polityczną (Partią Demokratyczną lub Republikańską) [88]. Wyniki sondażu przedstawia wykres 3.

W ankiecie „New York Timesa” 84\% głosujących stwierdziło, że ufa ekspertom medycznym dostarczającym wiarygodnych informacji o wirusie, 77\% takie zaufanie ma do CDC, a 67\% - do Anthony'ego Fauciego. Przedstawicielem środowiska politycznego w tym badaniu był urzędujący wówczas prezydent USA - Donald Trump, któremu w kwestiach związanych z pandemią COVID-19 ufało najmniej ankietowanych (jedynie 26\%).

Większym zaufaniem społeczeństwa cieszy się natomiast obecny prezydent Stanów Zjednoczonych - Joe 


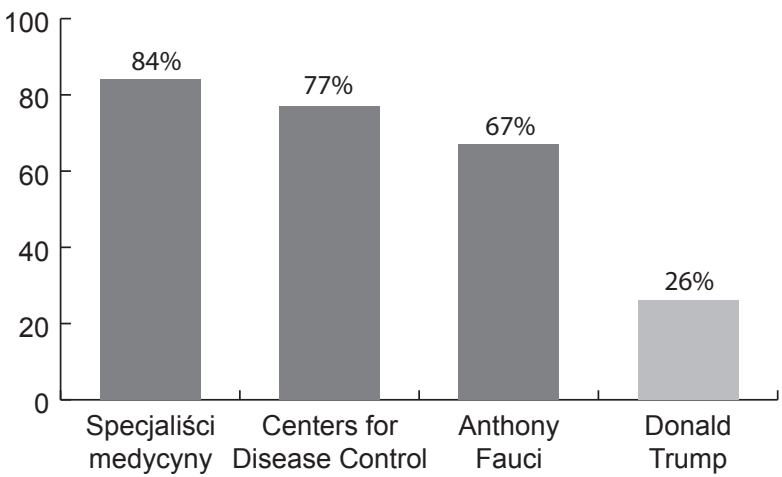

Wykres 3. Deklarowane zaufanie spoleczeństwa do ekspertów i instytucji eksperckich oraz polityków w USA

Źródto: opracowanie własne na podstawie [88].

Biden. Według danych przedstawionych przez „EurekAlert!" odsetek dorosłych Amerykanów, którzy ufają Joe Bidenowi jako przywódcy w najskuteczniejszej walce $\mathrm{z}$ pandemią COVID-19, stanowił 52\% vs. Donald Trump 39\% [89]. Inne badanie przeprowadzone przez Axios-Ipsos również wskazuje na rosnące zaufanie do obecnego prezydenta. Na pytanie dotyczące zaufania do Bidena w sprawach COVID-19 między 23 a 26 października 2020 roku 47\% ankietowanych zadeklarowało swoje zaufanie, które następnie wzrosło do 56\% w pierwszej połowie listopada [90]. Niskie zaufanie do Donalda Trumpa w sprawach związanych z koronawirusem niewątpliwie przyczyniło się do zwycięstwa Joe Bidena w wyborach prezydenckich [91].

Zarówno w Polsce, jak i Stanach Zjednoczonych w kwestiach związanych z pandemią COVID-19 widoczne jest większe zaufanie społeczeństwa do ekspertów z dziedziny nauk medycznych i okołomedycznych niż do polityków. $Z$ jednej strony tendencja ta nie powinna dziwić - są to eksperci z dziedzin ściśle związanych z medycyną i zapobieganiem chorób, mają więc wiedzę i wykształcenie niezbędne do tego, aby doradzać i wypowiadać się w kwestiach działań, jakie powinny zostać podjęte $\mathrm{w}$ ramach walki z pandemią. Z drugiej jednak strony niepokojące jest stosunkowo niskie zaufanie do polityków. Są to bowiem osoby, które rządzą $\mathrm{w}$ danym kraju, i to one najczęściej wypowiadają się publicznie na temat podjętych strategii i o niej decydują. Politycy powinni móc poprzez swój autorytet wpłynąć na zachowania ludności po to, aby nie dopuścić do rozprzestrzeniania się choroby i możliwie jak najszybciej nad nią zapanować. Brak zaufania do przedstawicieli tego gremium może być główną przeszkodą działań $\mathrm{w}$ walce $\mathrm{z}$ wirusem.

\section{Podsumowanie}

Zagrożenie, niepewność i pilność związane z kryzysami zwykle wzmacniają rolę przywódców, dając im swobodę podejmowania decyzji o dalekosiężnych konsekwencjach. Nieznany wirus wymagał od decydentów zwrócenia się do lekarzy i ekspertów od chorób zakaźnych, aby uzyskać wiedzę naukową i doświadczenie, które mają kluczowe znaczenie dla podejmowania decyzji administracyjnych i zdrowia publicznego oraz edukowania ludzi w walce $\mathrm{z}$ wirusem. I choć wiadomo, że polityka nie zawsze idzie w parze $\mathrm{z}$ nauką, w sytuacji globalnego zagrożenia pandemią współpracę między politykami a ekspertami należy uznać za konieczną. Dzięki doradztwu ekspertów politycy mogli lepiej zrozumieć skalę zagrożenia i podejmować skuteczne (choć nie zawsze) decyzje i wprowadzać różnego rodzaju nakazy i zakazy mające na celu ograniczenie rozprzestrzeniania się wirusa w społeczeństwie. Należy jednak zwrócić uwagę, że z początkiem epidemii decydenci zarówno w Polsce, jak i USA sceptycznie podchodzili do niektórych zaleceń ekspertów, między innymi noszenia masek ochronnych. Ich niekiedy odmienne stanowiska były wygłaszane publicznie, co mogło rodzić dezorientację i niepewność wśród społeczeństwa.

Brak spójności w zaleceniach i stanowiskach polityków i ekspertów bardzo często skutkował utratą zaufania społecznego. W obliczu pandemii ludzie oczekują od rządzących rzetelnych, sprawdzonych, popartych dowodami naukowymi informacji, a także podejmowania skutecznych działań, które zapewnią im bezpieczeństwo. Z drugiej strony rządzącym powinno zależeć na jak największym zaufaniu społecznym, gdyż jedynie wtedy będą oni mogli wpływać na zachowania ludzi i skłaniać ich do stosowania się do zaleceń. Odmienne stanowiska polityków i ekspertów w obu badanych krajach, które można było zauważyć podczas przyjmowania strategii walki z koronawirusem, utrudniały te działania i powodowały opór społeczny.

Widocznym problemem było także zatarcie granicy między rolą eksperta a polityka. W przypadku Polski zdarzały się sytuacje, kiedy trudno było odróżnić decydenta od przedstawiciela środowiska naukowego. Było to spowodowane pełnieniem tych dwóch ról jednocześnie - jak np. w przypadku byłego ministra zdrowia Łukasza Szumowskiego. W takich sytuacjach trudno ocenić, jaką rolę przyjmuje dana osoba i czy jej stanowisko eksperckie jest niezależne politycznie. Od ekspertów oczekuje się, aby ich opinie były oparte na wiedzy naukowej bez względu na korzyści czy niekorzyści polityczne wynikające $z$ przyjętego przez eksperta stanowiska w sprawie.

Walka z pandemią COVID-19 to problem globalny, który stał się wyzwaniem dla systemów zdrowotnych. Niewątpliwie uwidocznił on mankamenty i brak wydajności systemów ochrony zdrowia w wielu krajach na świecie. Jednak można wskazać także na pozytywne strony pandemii, traktując ją jako lekcję dla systemów, rządzących, ekspertów, a także dla społeczeństwa. Kraje wypracowały własne strategie, ucząc się z każdym dniem, jakie działania przynoszą najbardziej pożądane efekty, a ujawnione problemy systemowe mogą stać się motywacja do podejmowania korzystnych zmian w przyszłości. W dłuższej perspektywie poprawa profilaktyki, a nie leczenie chorób jest kluczem do promowania zdrowia populacji poprzez reformę polityki zdrowotnej w ramach przygotowań do przyszłych pandemii. 


\section{Prypisy}

${ }^{1} \mathrm{~W}$ powołanej wyżej informacji Sekretarza Prasowego jako przewodniczący zespołu przedstawiony został Alex Azar (Secretary of Health and Human Services), Pence czy Birx nie zostali wymienieni jako jego członkowie.

${ }^{2}$ Kudlow kilkakrotnie wypowiadał się w sprawie rozprzestrzeniania się koronawirusa, twierdząc, że w USA udało się go powstrzymać

${ }^{3}$ Mimo częstych różnic opinii między dr Fauci i prezydentem Trumpem, był osobą najbardziej wpływową, natomiast w mediach pojawiały się komentarze, że dyrektor CDC był marginalizowany.

${ }^{4} \mathrm{~W}$ federalnej strukturze USA bardzo wiele decyzji należy do kompetencji gubernatorów.

${ }^{5}$ „Swoje rekomendacje dotyczące wyborów prezydenckich przekażę wtedy, kiedy będę miał realne podstawy, dane dotyczące epidemii. Nie będzie to wcześniej niż w drugiej połowie kwietnia" - powiedział Łukasz Szumowski 2 kwietnia 2020 r.

${ }^{6}$ „Głosowanie w II turze wyborów prezydenckich jest bezpieczne pod względem epidemiologicznym" - powiedział Łukasz Szumowski 10 lipca 2020 r.

${ }^{7}$ Dopiero 30 lipca 2020 r. opublikowana została następująca informacja: „W Ministerstwie Zdrowia powołano sztab kryzysowy. Wszystko z powodu pandemii COVID-19 i rekordowych zakażeń".

${ }^{8}$ Dotychczas w Ministerstwa Zdrowia tylko dwóch ministrów nie było z wykształcenia lekarzami (dotyczyło to ministrów 1. i 2. rządu mniejszościowego Marka Belki).

${ }^{9}$ W USA federalna struktura państwa sprawia, że decyzje o restrykcjach były podejmowane przez gubernatorów, a nie przez rząd w Waszyngtonie.

${ }^{10}$ Minister Przemysław Czarnek twierdził, że ma być to czas powrotu do normalności, używając na tę okoliczność określenia: „take it easy” (z ang. nie martw się, spokojnie, wyluzuj).

${ }^{11}$ Pomimo obostrzeń związanych z pandemią wyrok Trybunału Konstytucyjnego wywołał masowe protesty w kraju i za granicą. Z informacji Komendy Głównej Policji wynikało, że w szczytowym okresie protestów - 28 października 2020 r. odbyło się w sumie 410 demonstracji, w których uczestniczyło ponad 430 tys. osób.

\section{Piśmiennictwo}

1. Espinoza B., Castillo-Chavez C., Perrings C., Mobility Restrictions for the Control of Epidemics: When do They Work?, „PLoS One” 2020, vol. 15 (7), doi:10.1371/journal.pone.0235731, https://journals.plos.org/plosone/article?id=10.1371/journal.pone.0235731 (dostęp: 5.09.2021).

2. Mackenzie J.S., Smith D.W., COVID-19: A Novel Zoonotic Disease Caused by a Coronavirus from China: What We Know and What We Don 't „Microbiology Australia” 2020, doi:10.1071/MA20013, https://www.ncbi.nlm.nih.gov/ pmc/articles/PMC7086482/ (dostęp: 5.09.2021).

3. WHO Director-General's Statement on the Advice of the IHR Emergency Committee on Novel Coronavirus, January 23, 2020, https://www.who.int/director-general/ speeches/detail/who-director-general-s-statement-on-the-advice-of-the-ihr-emergency-committee-on-novel-coronavirus (dostęp: 5.09.2021).
4. Williams S., Person-to-Person Spread of Novel Coronavirus Confirmed in China, „The Scientist” January 21, 2020, https://www.the-scientist.com/news-opinion/personto-person-spread-of-novel-coronavirus-confirmed-in-china--66995 (dostęp: 5.09.2021).

5. Li Q., Guan X., Wu P., Wang X., Zhou L., Tong Y., Feng Z. (2020). Early Transmission Dynamics in Wuhan, China, of Novel Coronavirus-Infected Pneumonia, New „England Journal of Medicine" 2020, vol. 382 (13), s. 1199-1207.

6. Lavazza A., Farina M., The Role of Experts in the Covid-19 Pandemic and the Limits of Their Epistemic Authority in Democracy, Frontiers in Public Health, July 14, 2020, doi:10.3389/fpubh.2020.00356, https:/www.frontiersin.org/articles/10.3389/fpubh.2020.00356/full (dostęp: 5.09.2021).

7. Since the ACA, Gaps in People's Coverage have been Shorter, The Commonwealth Fund, 2019, https://www. commonwealthfund.org/chart/2019/aca-gaps-peoples-coverage-have-been-shorter (dostęp: 5.09.2021).

8. Garg S., Kim L., Whitaker M., O'Halloran A., Cummings C., Holstein R., Fry A. (2020). Hospitalization Rates and Characteristics of Patients Hospitalized with Laboratory-Confirmed Coronavirus Disease 2019 - COVID-NET, 14 states, March 1-30, 2020, Morbidity and Mortality Weekly Report 2020, vol. 69 (15), s. 458-464. https://www.cdc.gov/mmwr/volumes/69/wr/mm6915e3. htm (dostęp: 5.09.2021).

9. Polacy mocno ograniczyli aktywność z powodu wirusa, Puls Biznesu, 20.03.2020, https://www.pb.pl/polacy-mocno-ograniczyli-aktywnosc-z-powodu-wirusa-985873?fbclid=IwAR0jJE7nRWfWwdrZqu8_ohp8V1DzmSax5 cNan2hFNHhmEy_NTaUsVpavnQ (dostęp: 5.09.2021).

10. Bogenschneider K., Corbett T., Evidence-Based Policy Making: Insights from Policy-Minded Researchers and Research-Minded Policymakers, London: Routledge, 2010.

11. Centers for Disease Control and Prevention, Our History Our Story, December 4, 2018, https://www.cdc.gov/about/ history/index.html (dostęp: 5.09.2021).

12. „CDC is a unique agency with a unique mission: We work 24/7 to protect the safety, health, and security of America from threats here and around the world". Por.: Centers for Disease Control and Prevention, A Bold Promise to the Nation, https://www.cdc.gov/about/24-7/index.html (dostęp: 5.09.2021).

13. Kates J., Michaud J., Levitt L., Pollitz K., Neuman T., Long M., Rudowitz R. et al., Comparing Trump and Biden on COVID-19, KFF, September 11, 2020, https://www.kff.org/coronavirus-covid-19/issue-brief/comparing-trump-and-biden-on-covid-19/ (dostęp: 5.09.2021).

14. Johns Hopkins University, Coronavirus Resource Center, 2020, https://coronavirus.jhu.edu/ (dostęp: 5.09.2021).

15. Kaiser Family Foundation, COVID-19 Tracker, KFF, May 13, 2020, https://www.kff.org/coronavirus-covid-19 (dostęp: 5.09.2021).

16. 1Point3Acres, Global Covid Tracker \& Interactive Charts, 2020, https://coronavirus.1point3acres.com/ (dostęp: 5.09.2021).

17. Johns Hopkins University, Coronavirus Resource Center, The COVID-19 Testing Insights Initiative, https://coronavirus.jhu.edu/about (dostęp: 5.09.2021). 
18. COVID-19 Data Reporting System Gets Off to Rocky Start, „The Wall Street Journal”, August 11, 2020, https://www. wsj.com/articles/covid-19-data-reporting-system-gets-offto-rocky-start-11597178974 (dostęp: 5.09.2021).

19. National Institute of Allergy and Infectious Diseases, NIAID History, February 20, 2012, https://www.niaid.nih.gov/ about/niaid-history (dostęp: 5.09.2021).

20. National Institute of Allergy and Infectious Diseases, NIAID Role in Research. Improving the Health of Millions of People Around the World, https://www.niaid.nih.gov/research/ role (dostęp: 5.09.2021).

21. Statements \& Releases Statement from the Press Secretary Regarding the President's Coronavirus Task Force, January 29, 2020, https://trumpwhitehouse.archives.gov/briefings-statements/statement-press-secretary-regarding-presidents-coronavirus-task-force/ (dostęp: 5.09.2021).

22. Santucci J., What We Know about the White House Coronavirus Task Force Now that Mike Pence is in Charge, USA Today News, February 28, 2020, https://eu.usatoday. com/story/news/politics/2020/02/27/coronavirus-what-weknow-mike-pence-and-task-force/4891905002/ (dostęp: 5.09.2021).

23. Statements \& Releases New Members of the White House Coronavirus Task Force Announced, May 15, 2020, https:// trumpwhitehouse.archives.gov/briefings-statements/newmembers-white-house-coronavirus-task-force-announced/ (dostęp: 5.09.2021).

24. D'Angelo G., Kudlow's Claim About COVID-19 Spread, FactCheck, May 5, 2020, https://www.factcheck.org/2020/05/ kudlows-claim-about-covid-19-spread/ (dostęp: 5.09.2021).

25. Hatcher W., Vick A., Public Health Issues in 2016 Presidential Campaign Communications, „American Journal of Public Health" 2018, vol. 108 (2), s. 191-192.

26. Hatcher W. (2019), President Trump and Health care: A Content Analysis of Misleading Statements, „Journal of Public Health" 2020, vol. 42, s. 482-486, https://doi. org/10.1093/pubmed/fdz176.

27. Sun L., Top White House Official in Charge of Pandemic Response Exits Abruptly, Washington Post, May 11, 2018, https:/www.washingtonpost.com/news/to-your-health/ wp/2018/05/10/top-white-house-official-in-charge-of-pandemic-response-exits-abruptly/ (dostęp: 5.09.2021).

28. Friedersdorf C. (2020, March 17). Trump Defended Cuts to Public-Health Agencies, on Video, The Atlantic, https:// www.theatlantic.com/ideas/archive/2020/03/trump-defended-cuts-public-health-agencies/608158/ (dostęp: 5.09.2021).

29. President Donald Trump Sits Down with CNBC's Joe Kernen at the World Economic Forum in Davos, Switzerland [transcript], CNBC, January 22, 2020, https://www.cnbc. com/2020/01/22/cnbc-transcript-president-donald-trumpsits-down-with-cnbcs-joe-kernen-at-the-world-economicforum-in-davos-switzerland.html (dostęp: 5.09.2021).

30. Wise A., Trump Accuses Dr. Fauci of wanting to ,play all sides" on re-opening, NPR, May 13, $2020 \mathrm{https://www.npr.org/}$ sections/coronavirus-live-updates/2020/05/13/855736912/ trump-accuses-dr-fauci-of-wanting-to-play-all-sides-on-reopening (dostęp: 5.09.2021).

31. Broad W.J., Levin D., Trump Muses About Light as Remedy, but Also Disinfectant, Which Is Dangerous, New York Times,
April 24, 2020, https://www.nytimes.com/2020/04/24/ health/sunlight-coronavirus-trump.html (dostęp: 5.09.2021).

32. Harwood J., Trump's Self-Defeating Resistance to Mask Wearing Says It All, CNN, June 28, 2020, https://edition. cnn.com/2020/06/28/politics/donald-trump-coronavirus-fallout/index.html_(dostęp: 5.09.2021).

33. Narodowy Instytut Zdrowia Publicznego - Państwowy Instytut Badawczy, Misja NIZP-PZH, https://www.pzh.gov. pl/instytut/o-instytucie/ (dostęp: 5.09.2021).

34. Narodowy Instytut Zdrowia Publicznego - Państwowy Instytut Badawczy, Historia, Biuletyn Informacji Publicznej, http://bip.pzh.gov.pl/public/?id=135928 (dostęp: 5.09.2021).

35. Ministerstwo Zdrowia, Zadania konsultantów krajowych, 20.08.2020, https://www.gov.pl/web/zdrowie/konsultanci-krajowi (dostęp: 5.09.2021).

36. „Każdy ekspert wie, że wybory korespondencyjne sa bezpieczniejsze od zwyklych", TVP Info, 02.04.2020, https:// www.tvp.info/47398100/kazdy-ekspert-wie-ze-wybory-korespondencyjne-sa-bezpieczniejsze-od-zwyklych (dostęp: 5.09.2021).

37. Spór o datę wyborów prezydenckich. Oto możliwe warianty, Polskie Radio 24, 27.04.2020, https://www.polskieradio24. pl/5/1222/Artykul/2499712,Spor-o-date-wyborow-prezydenckich-Oto-mozliwe-warianty (dostęp: 5.09.2021).

38. Prezydent o przełożeniu wyborów: „Bardziej ufam fachowcowi, jakim jest minister zdrowia niż politykom", Dziennik.pl, 23.04.2020, https://wiadomosci.dziennik.pl/ polityka/artykuly/7392800,prezydent-wybory-minister-zdrowia-koronawirus-covid-19-epidemia-pandemia.html (dostęp: 5.09.2021).

39. „Fakt” nieoficjalnie: Andrzej Duda naciskał na Łukasza Szumowskiego w sprawie wyborów, Gazeta.pl 03.04.2020, https://wiadomosci.gazeta.pl/wiadomosci/7,173952,2584 3694,fakt-nieoficjalnie-andrzej-duda-naciskal-na-lukasza-szumowskiego.html (dostęp: 5.09.2021).

40. Szumowski: „,Nie ma lepszych lub gorszych terminów, miesięcy na przeprowadzenie wyborów korespondencyjnych", TVN24, 17.04.2020, https://tvn24.pl/polska/lukasz-szumowski-przedstawil-zalecenia-w-sprawie-wyborow-prezydenckich-4558262 (dostęp: 5.09.2021).

41. Torchała K., Minister Lukasz Szumowski: „Zachęcam do pójścia na wybory”, Dziennik Wschodni, 10.07.2020, https://www.dziennikwschodni.pl/koronawirus/minister-lukasz-szumowski-zachecam-do-pojscia-na-wybory,n,1000269932.html (dostęp: 5.09.2021).

42. Ministerstwo Zdrowia, Konsultanci krajowi w dziedzinach lekarskich, 04.08.2020, https://www.gov.pl/web/zdrowie/ konsultanci-krajowi (dostęp: 5.09.2021).

43. Ministerstwo Zdrowia, Główny Inspektor Sanitarny powotany, 30.08.2018, https://www.gov.pl/web/zdrowie/glowny-inspektor-sanitarny-powolany (dostęp: 5.09.2021).

44. Andrzej Horban, Wikipedia, https://pl.wikipedia.org/wiki/ Andrzej_Horban_(dostęp: 23.03.2021).

45. Prof. Andrzej Horban: „Przekonaliśmy się, że istnieja choroby, które moga zdemolować świat”, Puls Medycyny, 09.03.2021, https://pulsmedycyny.pl/prof-andrzej-horban-przekonalismy-sie-ze-istnieja-choroby-ktore-moga-zdemolowac-swiat-1110559 (dostęp: 5.09.2021). 
46. Rządowe Centrum Bezpieczeństwa, Rządowy Zespół Zarządzania Kryzysowego, https://rcb.gov.pl/rzadowy-zespol-zarzadzania-kryzysowego/, (dostęp: 5.09.2021).

47. Ministerstwo Spraw Wewnętrznych i Administracji, Rzadowy Zespót Zarządzania Kryzysowego podjąt decyzję o odwołaniu imprez masowych, 10.03.2020, https://www. gov.pl/web/mswia/rzadowy-zespol-zarzadzania-kryzysowego-podjal-decyzje-o-odwolaniu-imprez-masowych (dostęp: 5.09.2021).

48. Obradowat Rządowy Zespół Zarządzania Kryzysowego. Temat: wyzwania zwiąane z COVID-19, Niezależna.pl, 22.03.2020, https://niezalezna.pl/317994-obradowal-rzadowy-zespol-zarzadzania-kryzysowego-temat-wyzwania-zwiazane-z-covid-19 (dostęp: 5.09.2021).

49. Lasota-Krawczyk J., Rzadowy sztab kryzysowy o możliwych obostrzeniach zwiazanych z koronawirusem, RMF24.pl, 31.07.2020, https://www.rmf24.pl/raporty/raport-koronawirus-z-chin/polska/news-rzadowy-sztab-kryzysowy-o-mozliwych-obostrzeniach-zwiazanych,nId,4642471 (dostęp: 5.09.2021)

50. Zarządzenie Ministra Nauki i Szkolnictwa Wyższego z dnia 25 marca 2020 r. w sprawie powołania Zespołu doradczego do spraw działań związanych z zapobieganiem, przeciwdziałaniem i zwalczaniem COVID-19, Dz.Urz. MNiSW 2020, poz. 20.

51. Zarządzenie Ministra Klimatu z dnia 30 marca 2020 r w sprawie powołania Zespołu Zarządzania Kryzysowego Ministra Klimatu w sprawie zagrożenia epidemicznego COVID-19, Dz.Urz. MK poz. 19.

52. Lista ekspertów Ministerstwa Zdrowia doradzajacych ws. epidemii koronawirusa, Polityka Zdrowotna, 20.05.2020, https://www.politykazdrowotna.com/59227,kto-doradza-ministrowi-zdrowia-ws-covid-192(dostęp: 5.09.2021).

53. W Polskiej Akademii Nauk powołano zespót doradczy ds. COVID-19, Nauka w Polsce, 01.07.2020, https://naukawpolsce.pap.pl/aktualnosci/news\%2C82894\%2Cw-polskiej-akademii-nauk-powolano-zespol-doradczy-ds-covid-19.html (dostep: 5.09.2021).

54. Zarządzenie Ministra Zdrowia z dnia 20 lipca 2020 r. w sprawie powołania Zespołu do spraw opracowania strategii działań związanych ze zwalczaniem epidemii COVID-19, Dz.Urz. MZ poz. 54.

55. Sztab kryzysowy w Ministerstwie Zdrowia. Będa obostrzenia?, Warszawa w pigułce, 30.07.2020, https://warszawawpigulce.pl/sztab-kryzysowy-w-ministerstwie-zdrowia/ (dostęp: 5.09.2021).

56. Zarządzenie Ministra Zdrowia z dnia 31 lipca 2020 r. zmieniające zarządzenie w sprawie powołania Zespołu do spraw opracowania strategii działań związanych ze zwalczaniem epidemii COVID-19, Dz.Urz. MZ poz. 56.

57. Zarządzenie Ministra Zdrowia z dnia 2 września 2020 r. w sprawie powołania Zespołu do spraw monitorowania i prognozowania przebiegu epidemii COVID-19 w Rzeczypospolitej Polskiej, Dz.Urz. MZ poz. 64.

58. Zarządzenie Ministra Zdrowia z dnia 4 września 2020 r. w sprawie powołania Zespołu do spraw działań związanych z zapobieganiem, przeciwdziałaniem i zwalczaniem COVID-19, Dz.Urz. MZ poz. 66
59. Łukasz Szumowski rezygnuje ze stanowiska, Puls Medycyny, 18.08.2020, https://pulsmedycyny.pl/lukasz-szumowski-rezygnuje-ze-stanowiska-999676, (dostęp: 5.09.2021).

60. Adam Niedzielski, Ministerstwo Zdrowia, 26.08.2020, https://www.gov.pl/web/zdrowie/adam-niedzielski (dostęp: 5.09.2021).

61. Adam Niedzielski: Chciatby, by NFZ stat się instytucja publiczna cieszaca się zaufaniem Polaków, Puls Medycyny, 26.02.2020, https://pulsmedycyny.pl/adam-niedzielski-chcialby-by-nfz-stal-sie-instytucja-publiczna-cieszaca-sie-zaufaniem-polakow-983446 (dostęp: 5.09.2021).

62. Adam Niedzielski: „Na razie nie będzie konkursu na stanowisko Głównego Inspektora Sanitarnego”, Medexpress.pl, 23.11.2020, https://www.medexpress.pl/na-razie-nie-bedzie-konkursu-na-stanowisko-glownego-inspektora-sanitarnego/79721 (dostęp: 5.09.2021).

63. Morawiecki: „Koronawirusa już nie trzeba się bać”, Termedia, 02.07.2020, https://www.termedia.pl/mz/Morawiecki-Koronawirusa-juz-nie-trzeba-sie-bac,38595.html (dostęp: 5.09.2021).

64. Wystapienie Mateusza Morawieckiego, 2.07.2020 https:// tvn24.pl/wybory-prezydenckie-2020/wybory-prezydenckie-2020-premier-mateusz-morawiecki-zacheca-do-udzialu-w-2-turze-wyborow-4626728 (dostęp: 5.09.2021).

65. Badora-Musiał K., Wymogi i nakazy dotyczace noszenia masek ochronnych, „Zdrowie Publiczne i Zarządzanie”, 2020, Tom 18, Numer 2, s. 155-164, www.ejournals.eu/ Zdrowie-Publiczne-i-Zarzadzanie, doi:10.4467/20842627 OZ.20.015.12768.

66. Czarnek o powrocie dzieci do szkót: będa zajęcia dodatkowe i wsparcie psychologiczne, Rzeczpospolita, 29.04.2021, https://www.rp.pl/Edukacja-i-wychowanie/304299949-Czarnek-o-powrocie-dzieci-do-szkol-beda-zajecia-dodatkowe-i-wsparcie-psychologiczne.html (dostęp: 5.09.2021)

67. Rozporządzenie Ministra Zdrowia z dnia 28 kwietnia 2020 r. w sprawie standardów w zakresie ograniczeń przy udzielaniu świadczeń opieki zdrowotnej pacjentom innym niż z podejrzeniem lub zakażeniem wirusem SARS-CoV-2 przez osoby wykonujące zawód medyczny mające bezpośredni kontakt z pacjentami z podejrzeniem lub zakażeniem tym wirusem, Dz.U. 2020 poz. 775.

68. Rozporządzenie Ministra Zdrowia z dnia 20 lipca 2020 r. zmieniające rozporządzenie w sprawie standardów w zakresie ograniczeń przy udzielaniu świadczeń opieki zdrowotnej pacjentom innym niż z podejrzeniem lub zakażeniem wirusem SARS-CoV-2 przez osoby wykonujące zawód medyczny mające bezpośredni kontakt $\mathrm{z}$ pacjentami z podejrzeniem lub zakażeniem tym wirusem, Dz.U. 2020 poz. 1275.

69. Zygiel A., Bezkarność urzędników w walce z Covid-19. PiS wycofuje projekt ustawy, RMF24, 17.09.2020, https:// www.rmf24.pl/fakty/polska/news-bezkarnosc-urzednikow-w-walce-z-covid-19-pis-wycofuje-projek,nId,4737379 (dostęp: 5.09.2021).

70. Kalisz M., Szuleka M., Wolny M., 2020. Pandemia, kryzys praworzadności, wyzwania dla praw człowieka, Warszawa: Helsińska Fundacja Praw Człowieka, 2021 https://www. hfhr.pl/wp-content/uploads/2021/02/2020.Pandemia-kry- 
zys-praworzadnosci-wyzwania-dla-praw-czlowieka-01-02 pdf (dostęp: 5.09.2021).

71. Minutes and Agendas from Meetings of the NPHET: COVID-19, GOV.IE, February 17, 2020 https://www.gov. ie/en/collection/691330-national-public-health-emergency-team-covid-19-coronavirus/ (dostęp: 5.09.2021).

72. Li Wenliang: Coronavirus Kills Chinese Whistleblower Doctor, BBC News, February 7, 2020, https://www.bbc. com/news/world-asia-china-51403795 (dostęp: 5.09.2021).

73. De Orte P., Nos EUA, Bolsonaro diz a plateia de empresários que coronavirus ,, não é isso tudo, muito é fantasia”. O Globo, March 10, 2020, https://oglobo.globo.com/economia/ nos-eua-bolsonaro-diz-plateia-de-empresarios-que-coronavirus-nao-isso-tudo-muito-fantasia-1-24296379 (dostęp: 5.09.2021).

74. Lipsitch M., Swerdlow D.L., Finelli L., Defining the Epidemiology of Covid-19 - Studies Needed, ,The New England Journal of Medicine" 2020, doi: 10.1056/NEJMp2002125, https://www.nejm.org/doi/full/10.1056/nejmp2002125 (dostęp: 5.09.2021).

75. Adams G., Walls R., Supporting the Health Care Workforce During the Covid-19 Global Epidemic, „Journal of the American Medical Association", 2020, doi: 10.1001/ jama.2020.3972, https://jamanetwork.com/journals/jama/ fullarticle/2763136 (dostęp: 5.09.2021).

76. Amesh A., Toner E., Inglesby T., Priorities for the US Health Community Responding to Covid-19, „Journal of the American Medical Association" 2020, doi: 10.1001/ jama.2020.3413, https:/jamanetwork.com/journals/jama/ fullarticle/2762690 (dostęp: 5.09.2021).

77. Lavazza A., Farina M., The Role of Experts in the Covid-19 Pandemic and the Limits of Their Epistemic Authority in Democracy, Frontiers in Public Health, July 14, 2020, https:// www.frontiersin.org/articles/10.3389/fpubh.2020.00356/ full?fbclid=IwAR1wpa2T6spV-FOCnzZ47txId5LolbXxmx2ECN9nRMW1XPVxoRSutfhkL4I\#note13 (dostęp: 5.09.2021).

78. Resnick D., Trust in Science and in Government Plays a Crucial Role in COVID-19 Response, International Food Policy Research Institute, June 10, 2020, https://www.ifpri. org/blog/trust-science-and-government-plays-crucial-rolecovid-19-response (dostęp: 5.09.2021).

79. Clarke J., Newman J., „People in this country have had enough of experts': Brexit and the paradoxes of populism, „Critical Policy Studies” 2017, vol. 11, s. 101-116.

80. Kennedy R.F., Russell D., Climate in Crisis: Who's Causing It, Who's Fighting It, and How We Can Reverse It Before It's Too Late, New York, NY: Skyhorse Publishing, 2020.

81. W walce z pandemia bardziej ufamy ekspertom niż politykom [WYNIKI SONDAŻU IBRIS DLA FAKTU], Fakt.pl, 20.01.2021, https://www.fakt.pl/wydarzenia/polityka/sondaz-ibris-dla-fakt-nazwiska-ludzi-ktorzy-walcza-z-pandemia-slabo-rozpoznawalne/7w4d8vb (dostęp: 5.09.2021).
82. Centrum Badania Opinii Społecznej, Marcowy ranking zaufania do polityków, Komunikat z badań nr 36/2021, marzec 2021, https://www.cbos.pl/PL/publikacje/raporty/open_file. php?url=2021/K_036_21.PDF\&tytul=Marcowy+ranking+z aufania+do+polityk;243;w (dostęp: 5.09.2021).

83. Centrum Badania Opinii Społecznej, Nastroje społeczne w grudniu, Komunikat $\mathrm{z}$ badań nr 161/2020, grudzień 2020, https://www.cbos.pl/PL/publikacje/raporty/open file.php?url=2020/K_161_20.PDF\&tytul=Nastroje + spo;32 2; eczne+w+grudniu (dostęp: 5.09.2021).

84. Centrum Badania Opinii Społecznej, Zaufanie do polityków w lutym, Komunikat z badań nr 24/2020, luty 2020 https://www.cbos.pl/PL/publikacje/raporty/open_file. php?url=2020/K_024_20.PDF\&tytul=Zaufanie + do + polity k;243; w+w+lutym (dostęp: 5.09.2021).

85. Centrum Badania Opinii Społecznej, Marcowy ranking zaufania do polityków, Komunikat z badań nr 41/2020, marzec 2020 https://www.cbos.pl/PL/publikacje/raporty/open_file.php?url=2020/K_041_20.PDF\&tytul=Mar cowy+ranking+zaufania+do+polityk;243;w (dostęp: 5.09.2021).

86. Centrum Badania Opinii Społecznej, Zaufanie do polityków na przełomie maja i czerwca, Komunikat z badań nr 69/2020, czerwiec 2020 https://www.cbos.pl/PL/publikacje/raporty/open_file.php?url=2020/K_069_20.PDF\&ty tul=Zaufanie + do + polityk;243; + +na + prze; $322 ;$ omie + maja $+\mathrm{i}+$ czerwca (dostęp: 5.09.2021).

87. Centrum Badania Opinii Społecznej, Zaufanie do polityków w lipcu, Komunikat z badań nr 90/2020, lipiec 2020, https://www.cbos.pl/PL/publikacje/raporty/open_file. php?url=2020/K_090_20.PDF\&tytul=Zaufanie + do+poli tyk;243; $\mathrm{w}+\mathrm{w}+$ lipcu (dostęp: 5.09.2021).

88. On Coronavirus, Americans Still Trust the Experts, The New York Times, June 27, 2020, https://www.nytimes. com/2020/06/27/upshot/coronavirus-americans-trust-experts.html?fbclid=IwAR37MfPsHFf46x_5r6a0baYQ7eJ8krUDNvpcQoPSTMJN0fYeGeWg73aQMv4 (dostęp: 5.09.2021).

89. Candidate Most Trusted to Lead U.S. Healthcare System Amid COVID-19, EurekAlert!, West Health-Gallup Post Debate National Healthcare Poll, September $30-$ October 1, 2020, https://www.eurekalert.org/multimedia/763934 (dostęp: 5.09.2021).

90. Axios-Ipsos Poll: Biden's Rising COVID Trust, November, 18, 2020, Axios, https://www.axios.com/axios-ipsos-poll-biden-covid-trust-214f3b6d-180d-491e-beea36d4a4ba695b.html (dostęp: 5.09.2021).

91. Kirzinger A., Kearney A., Hamel L., Voters Are Souring on President Trump's Handling of Coronavirus, with Implications for November, August 17, 2020, KFF, https:// www.kff.org/policy-watch/voters-are-souring-on-president-trumps-handling-of-coronavirus-with-implications-for-november (dostęp: 5.09.2021). 